\title{
A TALE OF TWO TRANSLATIONS: VAN LEEUWEN AND VAN DER LINDEN AND THE APPLICATION OF ROMAN-DUTCH LAW AT THE CAPE IN THE 1820s; TO WHICH IS APPENDED A TRANSCRIPTION OF PB BORCHERDS' 1822 TRANSLATION OF BOOK II OF VAN DER LINDEN'S KOOPMANS HANDBOEK
}

\author{
JP van Niekerk* \\ Gardiol van Niekerk*
}

\section{ABSTRACT}

The Roman-Dutch law applicable at the Cape of Good Hope survived the British take-over of the settlement at the beginning of the nineteenth century for a number of reasons. One of these was the increasing availability, through translations into English, of the main sources of that legal system. This contribution spotlights two hitherto little known such translations, of works of Van Leeuwen and Van der Linden. One of these was by a local Cape lawyer, PB Borcherds. Although partly typeset and printed, the translation was, for apparently spurious reasons, never published; had it been, it may well have been the earliest legal work published at the Cape. The translation, existing only as archival material, is here transcribed and published for the first time, almost two hundred years after it should have appeared.

Keywords: Roman-Dutch law; law at the Cape in the 1820s; role of translations; Van Leeuwen and Van der Linden

* Professors, School of Law, University of South Africa. 


\section{Introduction}

Several factors played a role in what has been termed the "remarkable survival" of Roman-Dutch law at the Cape of Good Hope in the nineteenth century. It survived despite the fact that when the territory became a British settlement in 1806, that legal system was finally cut off from its roots in the Netherlands and came to be subjected to a subtle but persistent process of anglicisation. In addition to the fact that a significant number of lawyers qualified in (Roman-) Dutch law continued to practice in Cape courts, ${ }^{1}$ a steady stream of translations into English of the most important sources of Roman-Dutch law in the course of the nineteenth century sought to make that system accessible to the increasing number of local lawyers who had an English background. $^{2}$

A particular problem faced the administration of justice in territories taken over by Britain where a legal system or systems other than English common law applied. The existing system was, in accordance with trite British constitutional principles, and at least for the time being, left unchanged; only a gradual and partial assimilation with English common law was usually envisaged and provided for. This meant that for the time being British judicial officers and civil servants had to apply a foreign legal system, with its sources invariably in a language other than English, to a population which, in many cases, included a growing number of English-speaking immigrants. The legal system with which we are concerned here is Roman-Dutch law, which was the main system ${ }^{3}$ applicable in the British colonies of Guiana, Ceylon and the Cape of Good Hope. Apart from a policy of gradual anglicisation - not only of the law, but also of its language, ${ }^{4}$ procedures and customs - another solution to this problem was to make the main sources of the applicable legal system accessible by means of translations. ${ }^{5}$ Given the larger aim of anglicisation, such translations were,

1 See, generally, Erasmus 2015.

2 See, in particular, Van den Bergh 2012: 86-87.

3 Other, often indigenous, legal systems also applied, but were not always formally recognised by incoming British administrations.

4 See, in particular, Van Niekerk 2015. On the process of anglicisation at the Cape at the beginning of the nineteenth century, see generally Freund 1989; Van der Burg 2011; and Van der Burg 2015.

5 For statutory sources, a related method was the compilation and publication (and often also the translation) of the various pieces of legislation promulgated not only in the Netherlands, in Batavia and in London, but also locally by Dutch and British colonial authorities. On the statutory sources of Cape law, see, eg, Sampson 1887; Roos 1897; and Roos 1906. The need for such a compilation of applicable laws was mooted during the Batavian interlude 1803-1806 but came to nought: see Visagie 1954: 42; and Van der Merwe 1986: 51 n 77. In 1819 a committee was appointed to compile and cast into a digested form the various pieces of legislation issued under previous administrations, but again without consequence: see Theal $R C C$ vol 33: 1 at 3-4. In 1825, governor Somerset was requested to compile a collection of Cape statutory law, indicating which promulgations were still in force: see Theal $R C C$ vol 20: 12-15. This resulted in the publication in 1826 of Proclamations, Advertisements and Other Official Notices Published by the Government of the Cape of Good Hope, from Jan 10, 1806 to May, 21, 1825, compiled by Sir Richard Plaskett and $\mathrm{T}$ Miller and containing the relevant pieces both in English and in (not always correctly translated) Dutch: see further Visagie 1954: 42-43; and Van der Merwe 1986: 51-52. A further 
at best, an intermediary measure and hence never generally and officially sanctioned. They appeared piecemeal and over a considerable period of time. There was no formal scheme for the official translation into English of foreign, including RomanDutch, legal sources to facilitate the colonial administration of justice in the relevant territories.

However, some translations did appear to have, if not official sanctioning or authorisation, then at least official backing and blessing. In this piece we are concerned with two such translations, involving two works of two well-known Roman-Dutch jurists, Simon van Leeuwen's Het Rooms Hollands Recht and Johannes van der Linden's Rechtsgeleerd, Practicaal, en Koopmans Handboek. ${ }^{6}$ Although the translations in question are not completely unknown, ${ }^{7}$ they are sufficiently obscure to justify their brief discussion here, the more so given that both seemingly featured prominently in the administration of justice at the Cape in the 1820s and that their provenance is of fascinating legal-historical interest. By the mid-1800s, the various translations of the two works in question were still significant for being of the very few works available in English on the general principles of Roman-Dutch law. ${ }^{8}$

\section{Van Leeuwen's Het Rooms Hollands Recht and its Ceylonese translation}

Simon van Leeuwen (1626-1682), with a doctorate from Leiden and a practising advocate, was the author and translator of several legal works, ${ }^{9}$ a number of which attained high authority in former Dutch territories before and in the course of the nineteenth century.

One of his early works, Paratitula juris novissimi, dat is: Een kort begrip van het Rooms Hollands Regt, published in Leiden in 1652, was the first to employ the term "Roman-Dutch law" in its subtitle. It, in turn, formed the basis of a more comprehensive work, ${ }^{10}$ entitled Het Rooms Hollands Recht, which appeared in Leiden and Rotterdam in 1664. This, his best-known work, went through several

Book of Statutes was compiled and published in 1862 by a commission (comprised of Sir William Hodges CJ; Bell, Cloete and Watermeyer JJ; attorney-general Porter; and colonial secretary Rawson), appointed by governor Sir George Grey in 1858. It contained unrepealed promulgations from 1652 and was annually updated thereafter under the title Statutes of the Cape of Good Hope.

6 As will become apparent, there were several translations of the two works in question, but the focus here is specifically on two of those translations as they had a significant Cape connection.

7 They are referred to in passing by Roberts 1942: 184 and 191 n, and by Farlam 2007: 400.

8 See Kahn 1985: 188-189, referring to the announcement by a Cape publisher (AS Robertson) in 1854 in which were mentioned the few legal works in English being available at the Cape, Ceylon, Guiana and in other countries where Roman-Dutch law prevailed.

9 See further Roberts 1942: 183-186; Dekkers 1951: 98-100; Van Zyl 1983: 354-358.

10 See Nadaraja 1972: 39 n 167. 
subsequent editions ${ }^{11}$ and was eventually, in $1780-1783$ in its 12 th edition, updated in two volumes with notes by Corneli(u)s Willem Decker.

The first translation into English of Van Leeuwen's Het Rooms Hollands Recht appeared in London in 1820, published by Joseph Butterworth and Son. Entitled Commentaries on the Roman-Dutch Law, it was a translation of the 11th edition of 1744 and was stated on the title page to have been translated from Dutch "by a native Cingalese, under the direction of Sir A Johnstone", and to have been edited by TH Horne. $^{12}$

The anonymous translator, or rather translators, it has been stated, were "the translators of the Supreme Court of Ceylon" at the time. ${ }^{13}$ The translation was made under the instruction of Sir Alexander Johnstone (1775-1849), a distinguished and influential colonial official, orientalist and judge in Ceylon until $1819,{ }^{14}$ when he returned to England for reasons of health. In 1832 he was made a privy councillor and in 1833 appointed to the Judicial Committee of the Privy Council, the establishment of which body as the court of final appeal in colonial litigation he had supported.

A reformer of judicial administration and supporter of the rights of indigenous inhabitants, Johnstone had in 1807 collected and reported on various local and customary laws in use in Ceylon so as to enable the new British officialdom better to understand and administer justice. In 1809 he had submitted several suggestions for the reform of the judicial administration on the island. Under his guidance, considerable advances were also made in the preparation of a compilation of the applicable law for Ceylon in which provision was made for the preservation of the indigenous laws and customs of local Hindus, Muslims and Buddhists. ${ }^{15}$

11 For example, the 5th ed appeared in 1678; the 6th ed in 1686; the 7th ed in 1698; the 8th ed in 1708; the 9th ed in 1720; the 10th ed in 1732; and the 11th ed in 1744 - all in Amsterdam.

12 We inspected a copy in the British Library which has on its spine the title Leeuwen Commentaries on the R-D Law. Roberts 1942: 184 has its title as Roman Dutch Law, translated anonymously from the 1744 edition by such translators as could be procured in Ceylon and notes the presence of copies in the libraries of the Supreme Court of Appeal in Bloemfontein and of the Cape High Court. Nadaraja 1972: $52 \mathrm{n} 234$ has it that on Johnstone's retirement from Ceylon, he presented his papers to the library of the Colonial Office (they are now in the National Archives (NA) at Kew, in CO 54/123-125), in which is contained (in CO 54/124 p 8a) a translation of the 1744 ed of Van Leeuwen's Het Rooms Hollands Recht, "made under the orders of Sir Alexander Johnstone by the translators of the Supreme Court". A revised version of this translation, with appendices, was the one published in London in 1820 by command of the Secretary of State.

13 See Nadaraja 1972: xxxvi.

14 Having studied law at Göttingen, Hanover, and at Lincoln's Inn, Johnstone was called to the bar in 1800, appointed to the post of advocate-general of Ceylon, and became acting chief justice in 1806, judge of the Supreme Court in 1807, and third chief justice of the island in 1811.

15 On Johnstone's career, see further Keene 2006; and Nadaraja 1972: 15, 53 n 237, 183. 
Significantly, the 1820 translation of Van Leeuwen's Het Rooms Hollands Recht also contained, by way of appendices, translations, made by Johnstone's "official translators", ${ }^{16}$ of various indigenous laws. ${ }^{17}$

The editor of the 1820 English translation of Het Rooms Hollands Recht was Thomas Hartwell Horne (1780-1862), a biblical scholar and bibliographer. ${ }^{18}$ Horne started off as a barrister's clerk and later, from 1806 to 1809 , became the private clerk to the publisher Joseph Butterworth, all the while cultivating his interest and honing his skills in the editing of books and the compilation of catalogues on various subjects, including theology and law. ${ }^{19}$ His appointment as editor of the Van Leeuwen translation in all probability stemmed from his acquaintance with its publisher.

In the preface to the 1820 translation of Van Leeuwen's Het Rooms Hollands Recht, the work is referred to as "the book to which the Dutch Courts of Justice on Ceylon most generally referred, as containing the System of Law which they were bound to administer to the Inhabitants on that Island". As the judges of the Supreme Court established by Britain on the island were directed to administer to those inhabitants the same system of laws as administered by Dutch courts previously, Sir Alexander Johnstone, while chief justice, "caused the present Volume to be translated into English, for the use of the Court, by such translators as he could procure on the Island". And because the work was also the basis of civil and criminal law in all those colonies that formerly belonged to Holland but which now formed part of the British Empire, the preface continued, "the following Translation has been printed by command of His Majesty's Secretary of State for the Department of War and the Colonies". It added that no pains had been spared to render the translation as accurate and perspicuous as possible, "so that the Work may form a useful Manual to professional Gentlemen on Ceylon, the Cape of Good Hope, and other Dutch Colonies now under the English Government, where the Dutch Laws

16 Nadaraja 1972: 52 n 234. One translator, the reverend Christian David of Jaffna, had translated several valuable Tamil works and had served in the Supreme Court as interpreter in important trials: idem 207 n 108.

17 The appendices (at 731-788) were, according to the preface, added to render the volume more useful as a manual of the actual law of Ceylon. They contained English translations of existing collections of laws and customs of two groups of native inhabitants, namely (1) a description of the established customs, usages and institutions according to which civil cases were decided among Malabar or Tamil inhabitants of (the province of Jaffna on) the island, aka the Thasavalema or Tésavalamai, originally collected under Dutch rule in 1706; and (2) the special laws concerning the Muslims (the "Moors or Mohammedans") in force on the island and collected by Johnstone in 1806. See further Nadaraja 1972: 46 n 207, 49 n 224, 183, 193 n 30.

18 See further Hawke 2006.

19 Among his numerous contributions were the following legal titles: compiler of A Compendium of the Statute Laws and Regulations of the Court of Admiralty, relative to Ships of War, Privateers, etc (1803); editor of the 2nd ed of Richard Lee Treatise on Captures in War (1803); editor of the 20th ed of Richard Burn Justice of the Peace (1805); editor of John Clark Bibliotheca Legum (1810); and editor of Thomas Pott Compendious Law Dictionary (1815). 
are still in force". And lastly, but not without significance, ${ }^{20}$ it was observed that as the system or "plan" of Van Leeuwen's work in a considerable degree resembled that of Blackstone's Commentaries on the Laws of England, it had been deemed proper to substitute the title Commentaries on the Roman-Dutch Law in lieu of the original title of the work.

\section{Van Leeuwen's Het Rooms Hollands Recht and its significance at the Cape}

No doubt in part because of the 1820 translation into English, Van Leeuwen's Het Rooms Hollands Recht had, and continued to enjoy, an elevated status as a source of the applicable Roman-Dutch law at the Cape after the British take-over. But was it ever at the Cape more than just one of the sources of that system?

In their Report on the Case of Mr Bishop Burnett, ${ }^{21}$ dated 7 December 1825, in describing the law applicable at the Cape, ${ }^{22}$ the commissioners then comprising the Commission of Eastern Inquiry - John Thomas Bigge and William MG Colebrooke - observed that the laws of Holland and Flanders were founded on Roman law and that these systems in combination had received the appellation of Roman-Dutch law. This legal system, they then tantalisingly continued, formed "the subject of a treatise composed by a learned civilian of Holland [that is, by Van Leeuwen] that has been translated into the English language, and under the auspices of your Lordship [Henry, third Earl of Bathurst, Secretary of State for the Colonies, 1812-1827], has been introduced as authority into the tribunals of those colonies that have been added to the British dominions, and in which the Dutch laws have been retained".

Taken at face value, this seems to imply that the English translation of Van Leeuwen's Het Rooms Hollands Recht, and in all probability then the 1820 Ceylonese one, had in some way or another been granted some kind of official status as a source of Roman-Dutch law in former Dutch colonies taken over by Britain, including, therefore, at the Cape. However, while true that the Ceylonese translation had been published in London on the instructions of the Secretary of State, we could trace no official record of such status. Otherwise than was subsequently the case in the Orange Free State or the Zuid-Afrikaansche Republiek, ${ }^{23}$ neither Van Leeuwen nor

20 See n 38 infra.

21 For background to this matter, see further Van der Merwe 1986: 37-42.

22 Theal $R C C$ vol 24: 72-107 at 103.

23 The Orange Free State Constitution of 10 Apr 1854 prescribed that the law would be RomanDutch law, including the works of Van Leeuwen and Van der Linden: see Van Zyl 1983: 468; and Eybers 1918: 285-296 at 295. Addendum no 1 to the Constitution of the Zuid-Afrikaansche Republiek of 19 Sep 1859 clarified the reference to the applicability of Dutch laws by explaining that the Koopmans Handboek of Van der Linden (in so far as it was as not in conflict with the Constitution or local statutes) would continue to be the official law-book and that when it did not treat a matter with sufficient clarity, or not at all, Van Leeuwen's Het Rooms Hollands Recht or 
his Het Rooms Hollands Recht was ever formally elevated to any official canon of authoritative sources of the law at the Cape. Equally, even though it was one of the so-called "books of authority" relied on by Ceylonese courts in their application of Roman-Dutch law, ${ }^{24}$ it seems not to have enjoyed that status even in Ceylon itself, whence the translation originated.

A possible explanation for the commissioners' statement, advanced by Fine, ${ }^{25}$ is that the British government sought to narrow the definition of "Roman-Dutch law" when the Secretary of State for the Colonies "introduced" a translation of Van Leeuwen's Het Rooms Holland Recht as "authority in former Dutch colonies", including at the Cape. Again, though, while that may indeed have been the motivation behind the official support or, at most, sanctioning of the translation, there is no evidence of how and when exactly the translation was "introduced" as "authority".

It seems, therefore, that the commissioners' statement should not be taken literally as suggesting that the unofficial ministerial imprematur given to the Ceylonese translation of Van Leeuwen's Het Rooms Hollands Recht elevated that work to the position of an authorised and, in some way, privileged source of Roman-Dutch law at the Cape. The translation was merely encouraged or supported to facilitate in the administration of Roman-Dutch law in those British colonies where, for the time being, it still applied.

But, of course, Van Leewen's work remained a favoured source of RomanDutch law at the Cape and a further English translation, by Sir John G Kotzé, ${ }^{26}$ this time of the 12th edition with Decker's notes, appeared in two volumes in London in 1882 and 1886 as Roman-Dutch Law; a second edition followed in 1921 and 1923.

\section{$4 \quad$ Van der Linden's Koopmans Handboek and its Guianese translation}

Johannes van der Linden (1756-1835), also with a doctorate from Leiden and a practising advocate in The Hague and later in Amsterdam, where he held several legal offices and was appointed to the bench in 1827 , was a prolific author and

Grotius's Inleidinge would enjoy binding authority: see Van Zyl 1983: 473; Eybers 1918: 362-409 and 416-417; and in particular Wildenboer 2015: 467, referring to "a constitutionally entrenched hierarchy of sources of law".

24 See Nadaraja 1972: 16, 280 n 243 who observes that Van Leeuwen's Het Rooms Hollands Recht, Van der Linden's Koopmans Handboek, and Voet's Commentarius ad Pandectas "were the books most commonly used by the Supreme Court" in the early years of British rule; copies of the Van Leeuwen translation were supplied to all the provincial courts on the island and it became the work most commonly used by provincial judges.

25 Fine 1991 vol 2: 469-470, 596.

26 As to whose judicial career on various benches in South Africa, see Roberts 1942: 367-368. 
prodigious translator of multiple legal and historical works; ${ }^{27}$ he was also a renowned bibliophile. ${ }^{28}$ Although actively involved in the codification movement in the Netherlands after 1795 as the drafter of several preliminary codes, he also wrote the last recognised work on the general principles of the Roman-Dutch common law, generally known as the Koopmans Handboek. It appeared in Amsterdam in 1806, the very year the Cape was returned to British possession.

With the full title Rechtsgeleerd, Practicaal, en Koopmans Handboek ten dienste van Regters, praktizijns, kooplieden, en allen, die een algemeen overzicht van regtskennis verlangen, it was, according to the author's preface, intended as an exposition of the general principles of the then current law of and legal practice in Holland for the instruction of persons unacquainted with or untrained in the law ("die, des Regts onkundig zijnde" and "hun, die, zonder gestudeerd te hebben, regtszaaken behandelen moeten"). The need for such a work was because Grotius's Inleidinge was too advanced for that group ("voor onkundigen veel te duister") while Van Leeuwen's Het Rooms Hollands Recht was by that time out of date. ${ }^{29}$

The work consisted of four books, namely on civil law, criminal law, legal procedure, and commercial law. Although its elementary and practical approach meant that it was not always recognised academically and in the Netherlands as a serious work on and an important source of the Dutch common law, ${ }^{30}$ that very feature made it an ideal text for non-lawyers and students seeking to come to grips with the basic principles of Roman-Dutch law. And, in fact, it became much more than that in the former Dutch colonies where British lawyers were active, mainly because it was relatively quickly translated into English.

The first English translation of the Koopmans Handboek appeared in Demerara, Guiana, in 1814. It is a rather obscure publication, seldom mentioned in legal bibliographies. In the preface to a later translation, that by Henry, ${ }^{31}$ the 1814 translation was stated to have been published "at Demerara by Mr van Braam,

27 See further Roberts 1942: 190-192 (who has it at 190 that Van der Linden was said to have been consulted in governmental matters by the authorities at the Cape after the British occupation); Dekkers 1951: 101; W[essels] 1907: 19-21; and Van Boven.

28 His collection of books was so extensive that he had to lease a warehouse in Amsterdam to store it.

29 As Lee 1915: v observed, both Grotius's and Van Leewen's treatment of Roman-Dutch law "inevitably leaves the reader in a state of bewilderment as to the nature and content of the RomanDutch Law administered at the present day by the Courts of South Africa, Ceylon and British Guiana". That was no doubt also true a century before.

30 See, eg, W[essels] 1907: 19-21, referring to the Koopmans Handboek as a "short sketch of the Roman-Dutch law", intended as textbook for students and for the uninitiated, and therefore very slight and not to be compared to, eg, Grotius's Inleidinge. In fact, he continued, a mastery of Van der Linden was insufficient to acquire a fair knowledge of Roman-Dutch law as his work was never intended to be more than "a first book to the student, or a legal vade mecum for the merchant" and "a mere preface to the study of the law of Holland".

31 About which more in due course: see par 5 infra. 
since deceased". Another source on publications in British Guiana, ${ }^{32}$ published in 1918, makes reference to "a most important book" printed by EJ [Edward James] Henery at the Royal Gazette Office there in 1814, a thick octavo of 418 pages, plus an appendix and index, entitled Judicial, Practical \& Mercantile Guide for the use of Judges, Lawyers, Merchants and all those who desire to have a general knowledge of Laws. Translated from the Dutch of Joannes van der Linden, LLD, Councillor at law at Amsterdam. With an appendix of some Law Terms, etc.

The work in question, the source continues, was of such importance that a translation was proposed in 1812 and a government notice issued offering a premium of 3000 guilders for a correct translation into English. The translator, it surmised, appears to have been one LP van Braam, although his name did not appear in the work. A good copy of the work, this source concludes, is housed in the library of the American Antiquarian Society in Worcester, MA. ${ }^{33}$

Likewise little certain is known of the probable translator, Van Braam, but scattered - and at times conflicting and confusing - pieces of information do emerge. He appears to have been Livius Paulus van Braam, born in Delft, apparently in 1791. ${ }^{34}$ One bit of supporting evidence relevant for present purposes is an advertisement that appeared in 1807 - when, if the date of his birth is correct, he was a mere sixteen years old - in the Essequebo and Demerary [Royal] Gazette that LP van Braam could be consulted as a "sworn translator in English, French, Dutch". ${ }^{35}$ That also means that he translated Van der Linden's work at the tender age of twenty-three. Van Braam died in Demerara in 1817 at the age of twenty-eight. ${ }^{36}$

32 Rodway 1918: 287. Cundall 1909: 73 lists “Judicial, Practical and Mercantile Guide of British Guiana. By Van der Linden. 1814", without identifying the translator.

33 We could not find any entry for the work in the online catalogue of the Society's library at https:// catalog.mwa.org, available on its website at http:www.americanantiquarian.org.

$34 \mathrm{He}$ is said in some sources to have been the son of vice-admiral Aegidius van Braam (1758-1822), who resided in England from 1795 to 1814, which might explain his son's proficiency in English: see "Van Braam, Jhr Aegidius" in http://stamboomonline.nl (accessed 2 Feb 2018) where it is mentioned that the admiral had three sons - Leonard, Marius and George - who had followed in their father's Naval footsteps and who were in Indonesia at the time of his death, while another son, Livius, also in the Navy, was (or rather, had been, if he predeceased his father) in Suriname in the West Indies. Conflicting evidence appears from "Surinaamse Genealogie", $s v$ "Jonkheer Livius Paulus van Braam", available at $h t t p: / / w w w . n e t w o r k 54 . c o m$ (accessed 23 Nov 2017); there he is stated to have been born in 1791 .

35 Other entries, which may or may not refer to our man, include: 15 Mar 1806 Essequebo and Demerary Gazette (mention of a "Van Braam, Esq, formerly Captain in the Dutch Navy" being appointed a grave digger to the colony, the editor not being able to resist observing that "[f] rom the number of applicants which we understand there was for this situation, it would seem that 'the loaves and fishers' [?] are no less an object of desire here than in Europe"); 27 Dec 1806 Essequebo and Demerary Gazette (mention of a Van Braam in Demerara offering a reward for the return of his boat that had become adrift from its chain or was stolen some three days before); a local proclamation (see Plakaatboek Guyana 1670-1816, available at http://resources. huygens.knaw.nl (accessed 4 Nov 2017)) dated 14 Dec 1811 concerning shipping movements, signed by LP van Braam as acting harbour master; and 24 Jan 1815 Demerary and Essequebo Royal Gazette, which, under the heading "General Colonial Order", mentions promotions and appointments in the Demerara Militia, including, "to lieutenant of LP van Braam, Gent, vice HB Fraser". The Gazettes are available at https:www.vc.id.au (and were accessed on 28 Nov 2017).

36 See Oliver 1914: 82-96 (Extract of the Obituaries of the Orphan Chamber of Demerara) where the following entry appears (at 86): "Van Braam, LP, d 3 Sep 1817". 


\section{The Henry translation of Van der Linden's Koopmans Handboek}

The 1814 Guianese translation of the Koopmans Handboek, it would appear, was a rather imperfect product; after all, if the translation was done by Van Braam, it was the work of a very young person, without any legal background and whose first language was not English. ${ }^{37}$

Although preparations were made for another translation, that only appeared many years later in 1828 in London. Entitled, rather incorrectly, ${ }^{38}$ Institutes of the Laws of Holland by Johannes van der Linden, LLD ... Amsterdam, printed in the year $1806 \ldots$, it was the work of Jabez Henry. According to the title page, the translation was done by the order of the Earl of Bathurst, Secretary of State for the Colonies, while Henry was described as being of Middle Temple, a barrister at law, and senior commissioner of legal enquiry into the administration of justice in the West Indian and South American colonies.

Jabez Henry (1775-1835) was a colonial judge and an early author in English on the conflict of laws. ${ }^{39}$ How and under what circumstances - and, crucially, as it will appear, when - he came to translate Van der Linden require a little closer inspection of his career.

Having qualified with a BA at Cambridge in 1806, he was admitted to Middle Temple and called to the bar in 1809 . From 1813 to 1816 he served as (the first English) president of the Court of the united colonies of Demerara and Essequibo, and of Berbice, recently acquired from the Dutch. In that capacity he administered both - Roman-Dutch - civil and criminal law. His appointment, like later ones, he owed to the influence of Earl Bathurst. After having resumed legal practice in England for a short period, he was in 1817 transferred to the Adriatic to become, in 1818, chief justice at Corfu and the first supreme judge of the Ionian Islands, where he encountered the Venetian legal system. ${ }^{40}$

In 1819 Henry again returned to London to practise - he was described in the Law List as an "Equity Draftsman and Conveyancer for the Dutch Colonies" - and, apart from a spell away as a member of a commission of enquiry into the administration

37 This was the view taken in the preface to Henry's subsequent translation.

38 See W[essels] 1907: 20, observing that the work's correct title in English is not Institutes of the Laws of Holland, but rather Practical Legal Manual. The Blackstone influence, perhaps?: see n 20 supra.

39 On Henry, see Nadelmann 1961a; Graham 2001; Graham 2005; Fletcher 2005 in pars 1.21-1.22; Graham 2006; and the Obituary "Jabez Henry, Esq" in Mar 1836 Gentleman's Magazine 324.

40 On one of his voyages to Corfu, the bibliophile Henry lost in a shipwreck his entire library of legal works, including those he had collected in Europe, a loss he much lamented. However, by the time of his death, his law and miscellaneous library had again grown substantially and a portion of it was sold at Sotheby's in London in 1834. On the significance to a bibliophile of a loss, whether by shipwreck or otherwise, of a personal library, see Edward Wilson-Lee The Catalogue of Shipwrecked Books, Young Columbus and the Quest for a Universal Library (2018) at 236. 
of justice in the West Indian and South American colonies from 1824 to $1825,{ }^{41}$ he proceeded to specialise in two niche areas, no doubt informed by his earlier judicial appointments and aided by his proficiency in Dutch, Italian and French.

The first was the increasingly important subject of private international law, in particular cross-border insolvency, a field in which he had some judicial as well as academic experience. ${ }^{42}$ Prior to the writings of Joseph Story, English courts relied to a large extent on the discussions of continental authors, especially those of the Dutch school and more specifically those of Huber, on issues of private international law. The most extensive work in English on the subject was by Jabez Henry, whose Foreign Law appeared in $1823 .{ }^{43}$

His other specialisation was foreign appeals to the Privy Council, ${ }^{44}$ in which Henry built up a large practice, often appearing in the company of illustrious English

41 He was appointed, in Mar 1824, as the senior commissioner to conduct an official enquiry into the administration of justice there. Several detailed reports by him or his fellow commissioners to the British parliament were the result. Of importance was Henry's Report in Apr 1828 on the united colonies of Demerara and Essequibo and the adjacent colony of Berbice, in which there is a sketch of the Roman-Dutch legal system that applied there. For further details, see Renton 1890, especially at 358-359.

42 His interest in the field was probably the result of an important decision (and the only reported one) that Henry had delivered in May 1814 as judge in the West Indies in Odwin v Forbes. At issue was Anglo-Dutch cross-border insolvency practice and Henry's decision was to the effect that under Roman-Dutch law a local creditor was not at liberty in the colony of Demerara to sue a debtor who had duly obtained a discharge from his debts in English bankruptcy proceedings in respect of a debt provable in those proceedings. A version of Henry's judgment (nothing more than a summary) was later published by John W Buck in his Cases in Bankruptcy vol 1 at 57-65, together with a report of the appeal dismissed without reasons by the Privy Council in May 1817. The two decisions are often referred to as Odwin v Forbes (1817) 1 Buck 57 (PC).

43 This work of Henry, published in London, was a pioneering and influential 295-page treatise on the conflict of laws, generally known by its short title Foreign Law; the full title was A Treatise on the Difference between Personal and Real Statutes, and Its Effect on Foreign Judgments and Contracts, Marriages and Wills. With an Appendix on the Present Law of France respecting Foreigners. Aimed at lawyers trained in the common law and treating the civil law relating to private international law for the first time in English, the work also contained, in its second half (at pp 86-189), an extended 90-page version of his 1814 Demerara judgment, with the relevant pleadings, in Odwin v Forbes, entitled [Report on] The Judgment of the Court of Demerara, in the Case of Odwin v Forbes, on the Plea of the English Certificate of Bankruptcy, in Bar, in a Foreign Jurisdiction, to the Suit of a Foreign Creditor, as Confirmed in Appeal, with the authorities, and foreign and English Cases. There is available a 2010 reprint of this work and its second half has also been published separately. For further background, see Lorenzen 1934: 19; and Nadelmann $1961 b$.

44 Prior to the establishment in 1833 of the Judicial Committee of the Privy Council (by the Judicial Committee Act, 1833 ( 3 \& 4 Will IV c 41), aka Lord Brougham's Act), colonial appeals were heard by a standing committee of the King's (Privy) Council (the King-in-Council), formally known as the Appeals Committee of his Majesty's Most Honourable Privy Council (or the Appeals Committee for short). It is before this body that Henry appeared in 1829-1830. The Committee comprised of all lords who were members of the Council and who attended its hearings under the chairmanship of the Master of the Rolls. They were usually not judicially qualified. The hearings took place in the Cockpit, near the site of 10 Downing St, where the Committee heard arguments in public and whence they then tendered a report or advisory "opinion" (as the judgments were 
lawyers. For instance, in 1829 to 1830, in the Council decisions reported in volume 1 of Knapp's Reports ${ }^{45}$ Henry appeared in several matters, on appeal from RomanDutch jurisdictions, ${ }^{46}$ including one from the Cape of Good Hope. ${ }^{47}$ The Council on numerous occasions referred to Henry's translation of Van der Linden in those and similar appeals and in one decision, on appeal from Demerara, ${ }^{48}$ it referred ${ }^{49}$ to "a very excellent book" on the law of Holland, "for a translation of which (Henry's translation of Vanderlinden's Institutes ...) the public are very much indebted to a Gentleman at this bar".

How and when did Henry come to translate Van der Linden? At least one earlier work gave an indication of his inclination to do so. In $1821^{50}$ he wrote a Report on the Criminal Law of Demerara and the Ceded Dutch Colonies: Drawn up by Desire of the ... Earl Bathurst ... with an Appendix on the Nature of the Office of Fiscal. Published in London by Henry Butterworth, in this slim 112-page volume

known) to the King-in-Council. Its decisions were not regularly reported until Knapp began his reports in 1829. On the hearing of colonial appeals prior to (the establishment of the Judicial Committee of the Privy Council in) 1833, see further Hodgins 1895; Egerton 1925; CJG 1935; Welsh 1950; Swinfen 1987: 1-8; Howell 1979: 1-22; and the "Introduction" to Taitz, Ackermann \& Barrow 1997: 1-6.

45 The reports of barrister Dr Jerome William Knapp, who held a DCL, were the first to be published of the decisions of the Privy Council: see Le Quesne 1952. They appeared as Reports of Cases argued and determined before the Lords of the Privy Council in three volumes (1829-1831, Aug 1831-Jun 1834, and 1834-1836) that are now available in 12 ER 222-377, 378-545, and 546-709 respectively. Knapp was also the co-author of Cases of Controverted Elections, \&c (see (1833) 10 Law Magazine, or Quarterly Review of Jurisprudence 146) and there is a caricature of him to be seen at https://antiqueprintmaproom.com (accessed 5 Feb 2018).

46 See Freyhaus v Cramer and Cantzlaar ([Jul] 1829) 1 Knapp 107, 12 ER 261, on appeal from Demerara, Henry appearing with Stephen Lushington (1782-1873), who held a DCL from Oxford and was a well-known civilian lawyer with a large practice in the High Court of Admiralty (he was later a judge there 1838-1867), in ecclesiastical courts, and also in the Privy Council (see further Waddams 2006); Nieuwerkerk v Reynolds (1829) 1 Knapp 151, 12 ER 278, on appeal from Berbice, Henry appearing with William Adam KC (1751-1839), a Scottish advocate with an LLD from Cambridge (see further Wilkinson 2006); Craig v Shand ([Feb] 1830) 1 Knapp 253, 12 ER 315, on appeal from Demerara, Henry appearing with Dr Lushington; and Frankland v M'Gusty and Pearce ([Feb-Jul] 1830) 1 Knapp 274, 12 ER 324, on appeal and cross appeal from Demerara, Henry appearing with Henry John Stephen (1787-1864), the son of lawyer and abolitionist James Stephen, who became serjeant-at-law in 1828 (see Stephen 2006).

47 See President and Members of the Orphan Board v Van Reenen ([Jul] 1829) 1 Knapp 83, 12 ER 252, (and see also Taitz, Ackermann \& Barrow 1997: 635) where Henry appeared before the King-in-Council with Brougham $\mathrm{KC}$ for the respondents, but where their reliance on a long passage from his Van der Linden translation was held not to be in point. Another Cape appeal from this time, Balston v Bird ([May-Jun] 1828) 1 Knapp 121, 12 ER 266, concerned the East India trade and the limits of the East India Co charter; Roman-Dutch law did not feature and neither did Henry.

48 Simpson v Forrester and Bach ([Dec] 1829) 1 Knapp 231, 12 ER 306; Henry appeared as amicus curiae: see at 243, 311.

49 Idem 241-242, 310.

50 Earlier, in 1817, he wrote An Essay on the Roman Law of Manumission of Slaves, and Its Application to the Colonies. 
Henry severely criticised the archaic and defective nature of the criminal process in the former Dutch colony of Demerara. One reason for this state of affairs was that the criminal law and procedure ordinances of Philip II of 1570 and 1580 were still applicable there. ${ }^{51}$ Significantly, this work contains a translation into English of what is termed a "Code of Criminal Law", being the Criminal Ordinance of Philip II of 1570 , followed by a commentary entitled a "Review of the Code". 52

Sometime after his return to London from the West Indies, ${ }^{53}$ and while busy or just having completed writing his Foreign Law, Henry was encouraged to undertake an English translation of Van der Linden's Koopmans Handboek by Sir William Grant. Grant had felt the need for a book of reference on Dutch law as it prevailed in the former Dutch colonies while presiding as Master of the Rolls in the hearing of colonial appeals in the Privy Council. ${ }^{54}$ The project was further supported and authorised by Earl Bathurst. Given his competence in several European languages, including Dutch, his earlier translation of (Roman-) Dutch legal materials, ${ }^{55}$ and his familiarity with the practical application of Roman-Dutch law in a British colony, Henry was no doubt one of the men in London best qualified for the task. Delayed by Henry's involvement with the West Indian commission of enquiry, he appears to have embarked on the translation sometime after 1824. In preparation, he travelled to Europe to collect material for the book, acquiring copies of works by respected continental jurists. In the process Henry visited Holland, "almost certainly" in connection with the translation and had a meeting with Van der Linden for this purpose. $^{56}$

The translation eventually appeared in 1828, entitled Institutes of the Laws of Holland. It was dedicated to Earl Bathurst, who had encouraged the work with his patronage and support while Secretary of State.

51 See further Lee 1914: 13; Davis 2011: 977.

52 There are also appendices, including one on the office of the advocate-fiscal or procureur-general. In a footnote in the Van der Linden translation, Henry recounted that he had in 1816 translated, "by the desire of Bathurst", the Criminal Code in force in Demerara, which translation was later appended to his Report on the criminal law of the colony.

53 The information in this paragraph appears from Henry's preface (dated Mar 1828) to the translation.

54 Sir William Grant (1752-1832), who had earlier for two years studied Roman-Dutch law at Leiden and had served as attorney-general of Quebec before commencing practising before the equity courts, was Master of the Rolls and, in that capacity, president of the Privy Council's Appeals Committee from 1801 to 1817 (see again n 44 supra). He retired in 1817, but for a few years after sat on the Committee and assisted in hearing colonial appeals. He was the only one of the English judges on the Privy Council prior to 1833 who had studied Roman-Dutch law and had an extensive knowledge and practical experience of civil law in other parts of the Empire; a DCL was conferred on him by Oxford in 1820. See further Fischer 2006.

$55 \mathrm{He}$ was also familiar with the ten-volume collection of decrees and ordinances of Holland, published from 1658 to 1797 - this is probably a reference to the Groot Placcaet-Boeck - of which the later volumes were under the editorship of Van der Linden.

56 See Graham 2001: 157, 160. Henry states in the preface that he went to Holland "for the express purpose of consulting the learned author himself on several points ... of importance, and in order to assure myself of the general accuracy of the Translation". 
In the preface, Henry referred to the earlier, 1814 (Van Braam) translation, a work then (in 1828) for some years out of print: "scarcely a copy (as I am informed) can be procured, either here [in England] or in the colonies". That alone, Henry judged, was enough reason for a new translation, but also because then the "want of technical precision" and the "inaccuracies of language" in the earlier one could be corrected. Another reason was that the Ceylon translation of Van Leeuwen's Het Rooms Hollands Recht, likewise evidently by a person but little acquainted with either English law or language, was also out of date and "no longer a safe book of reference, however valuable at the time" as it had never been updated. As Van der Linden's work, published in 1806, brought the ancient law of Holland, which still prevailed in the colonies ceded by the Dutch, up to that date, it was the ideal one for translation.

Henry recommended Van der Linden's work "to those who wish to acquire a competent knowledge of the civil law, to qualify them to hold judicial appointments in our foreign Colonies". The translation was specifically aimed at the expanding number of English lawyers, civil servants and colonial administrators increasingly being sent out to serve in former Dutch possessions where Roman-Dutch law still obtained. No doubt with this audience in mind, the translation contained numerous observations by Henry on the differences between the common and civil (RomanDutch) legal systems, as well as a lengthy chapter on the "Formation of a Select Law Library", which was an invaluable survey of legal source material for those who wished to acquire further knowledge. ${ }^{57}$

Henry's translation of Van der Linden's Koopmans Handboek became one of the most widely used source of Roman-Dutch law in British colonies for most of the remainder of the nineteenth century. Only in 1884 did a new English translation appear, in Cape Town by Henry Juta, ${ }^{58}$ under the title Institutes of Holland, or Manual of Law, Practice and Mercantile Law. ${ }^{59}$ Unsurprisingly, Juta reckoned that a new translation was due as Henry's earlier attempt, then in any case rapidly going out of print, was "not entirely free from inaccuracies" and as difficulties of copyright had prevented the correction and republication of that translation. And even if not the

57 Henry could not resist pointing out that most of them, in the choicest editions, were once in his possession, "at the cost of nearly a fortune", before they were lost by shipwreck on a passage to Corfu with almost everything else he owned: see n 40 supra.

58 Henricus Hubertus (Sir Henry Hubert) Juta (1857-1930) was at the time practising at the Cape bar. He later went on to become attorney-general of the Cape in 1894, speaker of the Cape House of Assembly from 1896 to 1898, judge president of the Cape Provincial Division from 1914, and judge of appeal from 1920: see further Roberts 1942: 366; and Davis 1915 who points out at 7 that Juta's translation of Van der Linden had "almost completely supplanted that of Henry". See also W[essels] 1907: 21, considering Juta's translation the "more correct one".

59 Further editions appeared in 1891, 1897 and 1906, and an abridged student edition entitled Van der Linden's Manual, commonly known as The Institutes in 1920. 
last one,${ }^{60}$ Juta's translation of Van der Linden's Koopmans Handboek is even today the one best known.

But, were it not for a not completely explicable quirk of history, yet another, earlier local translation too may have had some claim to notoriety.

\section{The Borcherds translation of book II of Van der Linden's Koopmans Handboek}

Petrus Borchardus Borcherds (1786-1871) ${ }^{61}$ was the son of the well-known dominee Meent Borcherds of Stellenbosch. He was taught first by his father and then by Dr Dolling, chaplain of admiral Sir Hugh Cloberry Christian, commander-in-chief of the Cape naval station. In 1800, at the age of fifteen, he was appointed as temporary clerk to the office of the district secretary of Stellenbosch, the notary Johannes Wege. From October 1801 to January 1802 he accompanied Dr PJ Truter, ${ }^{62}$ on his travels into the interior to conclude trade deals with indigenous tribes. In March 1803 Borcherds moved to Cape Town. There, through the intercession of the then president of the Court of Justice during the Batavian interlude, Dr Lambert CH Strubberg, who had studied with his father at Groningen, he was appointed as clerk to the Court, first under acting secretary (and later fiscal) Dr Daniël Denyssen, and then under his successor, Dr Gerrit Buyskes. He stayed on in this post after the return of the British government in 1806. At the end of 1809, he was appointed secretary of Stellenbosch and in March 1813 he was promoted to the post of deputy fiscal under his former boss, fiscal Denyssen. Borcherds remained in that post for almost ten years.

In 1823, after having occasionally taken a seat, Borcherds was appointed as a member of the Court of Justice. ${ }^{63}$ At the time the Court was comprised of some highly qualified lawyers and even the non-lawyers, such as Borcherds himself, had considerable practical legal experience ${ }^{64} \mathrm{He}$ had acquired his legal knowledge by

60 In 1914, yet another translation, of books I and II, and selections from books III and IV, by the Scotsman George Thomas Morice (1858-1930), at the time practising and teaching law in South Africa, appeared under the title Institutes of the Laws of Holland; a second edition followed in 1922. On Morice, see Roberts 1942: 392; and Anon 1929, who has it that this translation, accompanied as it was with notes, appeared because of Morice's involvement with law students.

61 On Borcherds, see the entry under his name in the Nieuw Nederlandsch Biografisch Woordenboek

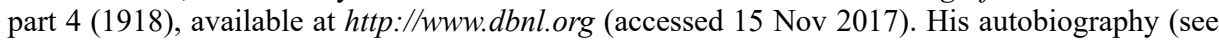
text at $\mathrm{n} 70$ infra) is also a rich source of information. We could not obtain copies of the following: C Borcherds Genealogy of the Borcherds Family (1964), and C Borcherds A Borcherds Tapestry: Addendum to Borcherds Memoirs by PB Borcherds (196?).

62 On Petrus Johannes Truter (1775-1867), medical doctor, civil servant and later, in 1819, member of the Court of Justice, see further DSAB vol IV: 663-664.

63 Borcherds was appointed in the place of Clemens Matthiessen, who had retired on pension; in his place, WC van Ryneveld was appointed deputy fiscal: see 22 Feb 1823 Cape Town Gazette.

64 At the time of Borcherds' appointment, the Court consisted of Dr Johannes Andreas (Sir John Andrew) Truster as president, Dr William Hiddingh, Dr Walter Bentinck, Dr Johannes Henoch Neethling, Frans Rynard Bresler, Johannes Christiaan Fleck, Petrus Stephanus Buissinne, and Petrus Johannes Truter jnr. Dr Daniël Frederick Berrangé was the Court's secretary, and both the fiscal (Denyssen) and the deputy fiscal, Johannes Lind, were also doctors of law. 
copying court records in long hand and after hours while keeping the protocol of Gerrit Buyskes, then an advocate and notary public. His legal bible was Van der Linden's Koopmans Handboek, to which he had been introduced by Strubberg. ${ }^{65}$

In 1828, after the Court of Justice had been replaced by the newly constituted Supreme Court, which was manned by imported British judges, Borcherds was redeployed and appointed to the office of Judge of Police, for Cape Town and its district, and for the Cape District. ${ }^{66}$ He later became a civil commissioner and magistrate until his retirement in February 1857 at the age of seventy-one.

As a prominent civil servant and well-connected ${ }^{67}$ Cape Angloman, Borcherds was from early on active on government business. Notably, in the early 1820 s, he collected materials for the Commissioners of Eastern Inquiry. ${ }^{68}$ In addition, Borcherds was active as an author and editor, ${ }^{69}$ and is best known today for his autobiography entitled An Autobiographical Memoir, which appeared in Cape Town in $1861 .{ }^{70}$

It is therefore unsurprising that when, in the early 1820 s, the question of the accessibility of Roman-Dutch legal sources at the Cape and the possibility of translation was raised, Borcherds should have become involved. Under the guidance and with the assistance - or maybe just the encouragement - of the president of the Court of Justice, Sir John Truter, ${ }^{71}$ Borcherds set out to translate a portion of Van der Linden's Koopmans Handboek, more specifically the part - book II - on criminal law. This portion was no doubt chosen because that was the area of law where the need for a translation to assist local legal administrators and others unfamiliar with the applicable Roman-Dutch law, was most keenly felt. ${ }^{72}$ Referring to his translation

65 See Borcherds 1861: 287, 482; Cowen 1959: 7.

66 See 17 Jan 1828 Cape Town Gazette.

67 He had married Janette Johanna Blankenberg in 1806.

68 See Ross 1999: 48 n 36.

69 It was probably Borcherds himself, and not his father Meent, who edited Jan van Riebeeck's Dagverhaal, which was serialised in Het Nederduitsch Zuid-Afrikaansch Tijdschrift from1824 to 1840; Borcherds also published several historical articles in that periodical: see Ross 1999: 48-49.

70 It was reprinted in 1963. The Memoir has the distinction of containing an early reference in Dutch to "colf" and "kolf" at 194, where there is a description of the "kolfbaan" in Stellenbosch as about 100 feet long and 30 feet across and covered and shaded by leaves and branches; see the KNKB [Koninklijke Nederlandsche Kolfbond] Webmuseum, available at http://www.colf-kolf. $n l$ (accessed 15 Nov 2017) and also Stander 2000: 21, referring to the Memoir and Borcherds' recounting that at the turn of the century school children went to the Braak where they played "kite" and ball games.

71 For the involvement of Sir John, see Borcherds 1861: 308 (referring to Truter's "guidance") and 487 (his "assistance"). In the preface to his translation, Borcherds acknowledged "the kind indulgence" of Truter in revising his work.

72 Borcherds 1861: 487 wrote that he undertook to translate Van der Linden's "criminal code" "for the information of the number of strangers who had settled in the colony and for general use". The same sentiments appeared in the preface to his translation. The aim was to give that part of Van der Linden's work relating to criminal jurisprudence "an English Dress", though without departing from "the genuine sense" expressed by the author "or giving any thing but what is truly Dutch Law". The translation was therefore "free rather than strictly literal". It was "intended chiefly for the use of my English Friends" who were desirous to be acquainted with the general principles of Dutch criminal procedure and would also like to compare it "with their own excellent and comprehensive" system. Lastly, "as a Foreigner", Borcherds acknowledged the assistance of a unnamed friend in casting his translation in idiomatic and stylish English. 
as being of Van der Linden's Code of Criminal Law, ${ }^{73}$ the work was already for the most part typeset by the Government Press in Cape Town ${ }^{74}$ on the instruction of governor Somerset - to whom it was also dedicated - when, in 1822, its intended publication was cancelled.

The reason, Borcherds explained in his Memoirs many years later, was that an edition had arrived at the Cape "of a translation of the whole of the author's work by mr Henry, so that mine was not necessary". ${ }^{75}$ So, the completed translation, partly printed, was never published.

But this cannot be right. Henry's translation of the (whole of the) Koopmans Handboek only appeared some years later, in 1828. What had arrived at the Cape, around 1822, it may be surmised, was either a copy of Van Braam's 1814 translation of Van der Linden, or, more likely, a copy of Henry's English translation of the Criminal Ordinance of Philip II that had appeared in $1821 ;^{76}$ or maybe not even an actual copy of the latter work, but simply news of its publication. In all probability, Borcherds' memory simply failed him all those years later when, in his old age, ${ }^{77}$ he recalled in his Memoirs why his translation had never seen the light. Whatever the explanation, it appears that the publication of Borcherds' translation may have been cancelled for insufficient a reason. Had it appeared, it may well have been the first legal text published at the Cape of Good Hope.

73 Roberts 1942: $191 \mathrm{n}$ refers to it as a translation in English of the "Code of Criminal Law' as comprised in the second book of a work on the Laws of Holland by Johannes van der Linden".

74 After an initial private initiative (messrs Walker and Robertson were in 1800 appointed as the sole printers to the Cape government), the printing press soon reverted to governmental control. That remained the position until the arrival of the Scots printer George Grieg in Mar 1823, all printing in Cape Town being done by the government. Unfortunately there is no complete record of what publications were undertaken on behalf of the general public (as opposed to official publications), but the first such appears to have been a religious pamphlet written by father Meent Borcherds, published in 1801. The actual typesetter of the translation was probably Andreas Richert (17631830), who had arrived at the Cape in 1803, and was superintendent of the Printing Office from Aug 1821 until Aug 1825: see further Lloyd 1914: 35, 37, 41-42; Smith 1971: 23-24.

75 Borcherds 1861: 308, and see also at 488: printing was ceased when Mr Henry's translation of the whole treatise arrived in the colony and Borcherds found that his was not necessary, "and hence it was not completed for publication".

76 Fine 1991 vol 2: 469-470 explains that Borcherds was instructed to compile an English translation of the criminal-law section of Van der Linden's Koopmans Handboek, but that, although (partly) printed in 1822, it was not distributed (published), presumably because the translation of Van Leeuwen's Het Rooms Hollands Recht had been introduced as authority at the Cape. We have already suggested that such introduction was unlikely and is in any event not supported by any available evidence: see text at n 25 supra.

77 Murray 1894: 97, 98 describes Borcherds as "the old gentleman, who was one of the most patient and amiable of men and certainly one of the most just and impartial of magistrates who ever sat upon the magisterial bench" and as "a grand old man in every respect, grand in appearance and in character, always ready to do a good turn for any one in need or in trouble, respected by the Government and revered by the public". "He must have been a fine, handsome man in his younger days", Murray concludes, for "[h]e was handsome even as he was venerable in his old age". 


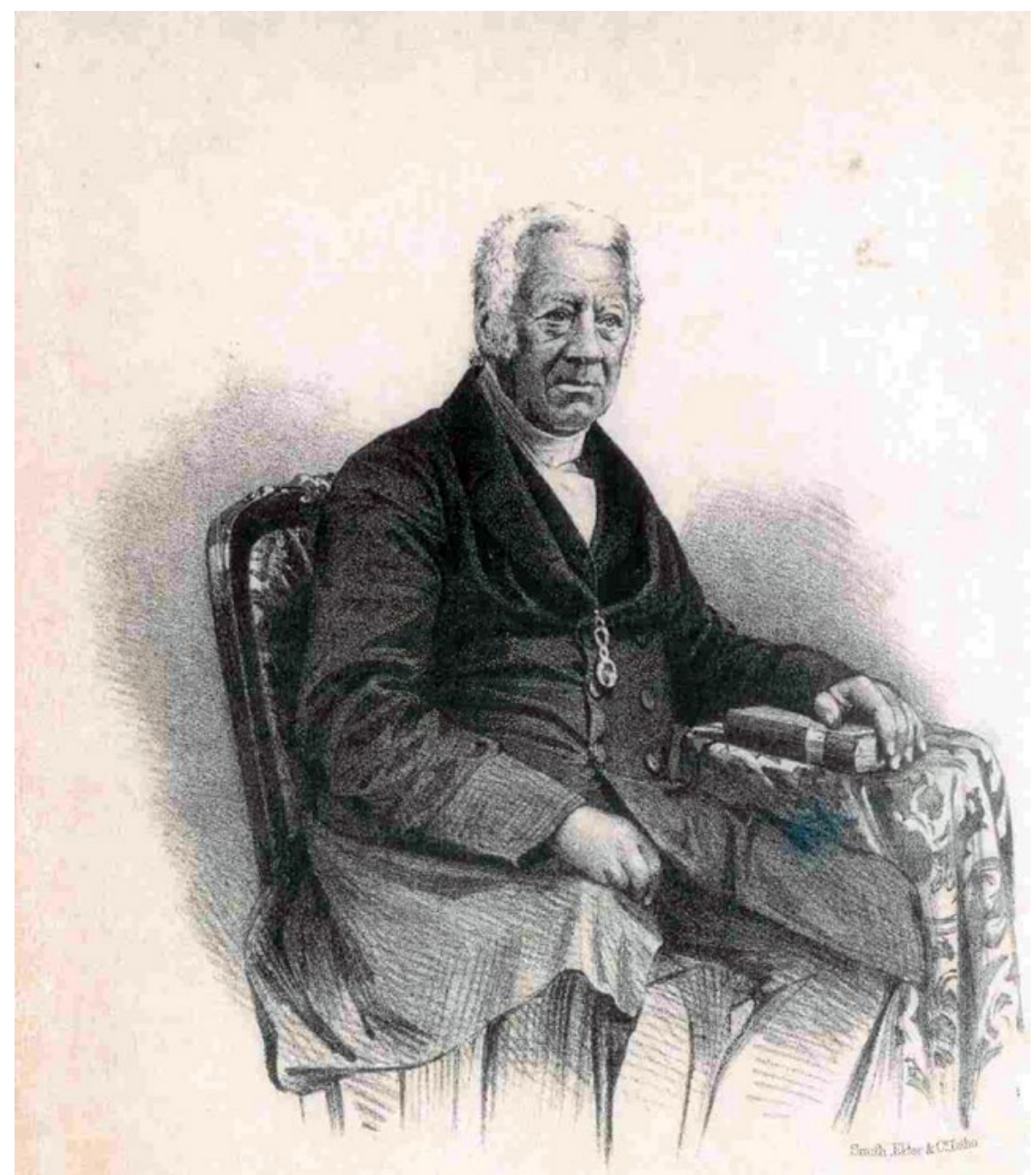

A portrait of Borcherds, in his old age, appearing as the frontispiece to his Memoirs

Although never published, Borcherds' translation, partly typeset in print and partly still in the form of the hand-written manuscript, did feature in the transformation of the law at the Cape. In their Report on Criminal Law and Jurisprudence, dated 18 August $1827,{ }^{78}$ the then Commissioners of Eastern Inquiry - John Thomas Bigge, William MG Colebrooke, and William Blair - referred" ${ }^{79}$ to a "meritorious attempt

78 See Theal RCC vol 33: 1-129.

79 Idem at 5, 29-31. 
[that] was recently made to furnish an explanation of the leading principles of the Dutch Criminal Law, and to introduce them to the knowledge of the English part of the Community, by the translation of a treatise on the Criminal Law [sic] published in Holland in 1806 by an eminent Dutch Jurist [Van der Linden]". They continued that it was "to be regretted that circumstances should have retarded the completion of a work which was peculiarly calculated to supply information to the magistrates and the secretaries of the country Districts, both of whom act as Public prosecutors".

Their Report contains several references to the views of Van Leeuwen and Van der Linden on aspects of criminal law. ${ }^{80}$ Quite possibly the commissioners made use of Borcherds' translation, for among the enclosures to their Report is contained, as enclosure 31, the "Translation into English of Code of Criminal Law, as comprised in the Second Book of a Work on the Laws of Holland by Johannes van der Linden, LLD, by PB Borcherds. Printed at the Government Press, Cape of Good Hope, in 1822". ${ }^{81}$ Although not reproduced with the Report by Theal at the end of the nineteenth century, the translation is still extant in the National Archives in London as part of the holdings containing the Commission's Report. ${ }^{82}$

Borcherds' translation, in the form of a transcription of both the typeset part and the hand-written manuscript part, appears, just shy of almost two centuries after it should have been published, as an appendix to this article. We have resisted the temptation to edit the translation and to cast it in a modern idiom and format, and have intervened (by way of squared brackets) only where it appeared necessary for the sake of clarity, to avoid misunderstanding, and to eliminate patent errors and omissions. In short, we have largely left Borcherds' translation as it would - should - have appeared in 1822.

\section{Conclusion}

The "remarkable survival" of Roman-Dutch law in Southern Africa in the nineteenth century was due to the presence of qualified lawyers practising at the Cape, and to the translation into English of the main sources of that legal system. Locally such translation ${ }^{83}$ commenced with the work of Borcherds in 1822, and continued

80 There are references, eg, to Van der Linden "in his [law] Manual", to him "in his Practical Law Handbook", and to him as "a Modern Author of repute": see Theal RCC vol 33: 207, 219.

81 See Theal RCC vol 33: 130-387 (the enclosures) at 340 (enclosure 31). However, for understandable reasons enclosure 31 is not one of those reproduced by Theal.

82 See NA, CO 48/129 (Commissioners of Eastern Enquiry, Appendix to Report on Criminal Law and Jurisprudence, Part 2), folios 325-354: the typeset part appears in folios 325-334a, the manuscript part in 345-354. Part 1 of the appendices is in CO 48/128, while the Report itself is in CO 48/120.

83 The continued relevance of the old Roman-Dutch authorities in modern South African law drawing upon its common-law roots - as to which see, eg, Farlam 2007 - was greatly facilitated by a remarkable efforts of mainly local lawyers in translating those authorities from Latin or Dutch into English or Afrikaans. On these endeavours, until relatively recently (but no longer) supported by the South African Law Reform Commission, see especially Hewett 2000; and Veen 2001 . 
apace throughout that century and for the whole of the next. Roman-Dutch sources, or at least the most prominent of them, became and remain available in modern translations, often with commentaries and notes.

Sadly, though, that alone will not suffice to prevent the steady decline of the influence of Roman-Dutch law in South Africa. There are historical precedents aplenty for such a decline, most pertinently in the two jurisdictions that featured earlier, Ceylon ${ }^{84}$ and Guiana. ${ }^{85}$ And the reason, or at least one of the main reasons, for it, is probably no different here: the dearth of local lawyers qualified in and passionate about that system. Woefully inadequate legal training, strong sentiments of anti-colonialism, and the fact that large swathes of the common law are continuously being supplanted

84 In Ceylon (today Sri Lanka), a British colony from 1802, Roman-Dutch civil and criminal law was and remained the subsidiary common law for Europeans and the indigenous populations alike: see Cooray 1974; and Van den Horst 1985. However, the local courts were said to have had a somewhat "eclectic attitude" to adopting and applying only those common-law principles that suited local civilisation and conditions: see Tambiah 1972: 128-130. Deficiencies in the common law, perceived or otherwise, were often made good by the adoption of English legal principles, more accessible to those trained in that system and enhanced by the fact that English had become the language of administration and the law: the English model was followed in legislation, judgments and pleadings, as well as in forms, conventions and traditions, and ceremonies. This resulted in a divergence between Roman-Dutch law as it applied in Ceylon and Roman-Dutch law as it prevailed in the Netherlands: Nadaraja 1972: 229. Further, indigenous systems of customary law gained recognition and, as far as these applied, Roman-Dutch law was relegated to a subsidiary law. And then the Roman-Dutch common law was superseded by English maritime and commercial law (in 1852 and 1866 respectively) and by English criminal law (in 1883). In the course of time, especially after 1820, a number of (English) judges and advocates in Ceylon did become profound civilian, Roman-Dutch lawyers (see Renton 1932: 173), but this did not last and soon, and for many decades later, there was a dearth of professional lawyers, qualified in (RomanDutch) law, untrained civil servants being appointed to administer justice in the lower courts: see Nadaraja 1972: 79 n 2, 87 n 143.

85 In Guiana (today, Gyana), a British colony from 1815 (it comprised Demerara, Essequibo and, from 1831, Berbice, when it became British Guiana), Roman-Dutch law likewise remained the subsidiary common law: see Lee 1914: 11-12. This irked immigrating British settlers and merchants, causing them "the most tortuous legal and economic frustrations", the more so as the continued use of the Dutch language and law allowed remaining Dutch interests, despite political control being vested in British hands, to seek "through the machinery of the law to re-establish and confirm Dutch economic power": see Farley 1955: 43, 45. In part as a result of Henry's Report (see n 41 supra), the existing criminal procedure was in 1828 and 1829 replaced by English procedure and court rules, while the civil procedure was gradually changed and approximated to English procedure: see Lee 1914: 13-14; and Ledlie 1917: 211. The unsuitable Roman-Dutch criminal law itself was replaced in 1846 by a series of ordinances introducing English principles; and English commercial law was introduced in 1864: Lee 1914: 15. In Guiana, too, a familiar problem arose, that of English-trained lawyers in charge of the administration of a legal system largely foreign and inaccessible to them: Ledlie 1917: 212. Ultimately, and although resisting assimilation more successfully than elsewhere in the West Indies (eg, in Trinidad where Spanish law was soon abolished), in 1917, the Civil Law of British Guiana Ordinance 1916 came into force and largely replaced the Roman-Dutch law by English common law so that, today, only isolated vestiges of the old system remain: see Glenn 2008: 53, 66. 
by legislative enactment will, it may be surmised, probably sooner rather than later, result in the "unremarkable demise" of Roman-Dutch law in its last stronghold.

\section{BIBLIOGRAPHY}

Anon (1929) "Mr GT Morice" SALJ 46: 137-139

Borcherds, PB (1861) An Autobiographical Memoir (Cape Town)

CJG (1935) “The Privy Council” SALJ 52: 277-285

Cooray, LJM (1974) "The reception of Roman-Dutch law in Sri Lanka" Comparative and International Law J of Southern Africa 7: 295-320

Cowen, DV (1959) "The history of the Faculty of Law in the University of Cape Town, 18591959” Acta Juridica: 1-19

Cundall, Frank (1909) Bibliography of the West Indies (excluding Jamaica) (Kingston, Jamaica)

Davis, RPB (1915) “The honourable Sir Henry Juta” SALJ 32: 1-10

Davis, Natalie Zemon (2011) “Judges, masters, diviners: Slaves' experience of criminal justice in colonial Suriname" Law \& History Review 29: 925-984

Dekkers, René (1951) Bibliotheca Belgica Juridica. Een bio-bibliographisch overzicht der rechtsgeleerdheid in de Nederlanden van de vroegste tijden af tot 1800 (Brussels)

Dictionary of South African Biography [DSAB] 5 vols (1968-1987) (Pretoria)

Egerton HE (1925) "The seventeenth and eighteenth century Privy Council and its relations with the colonies" J of Comparative Legislation \& International Law 3rd Series 7: 1-16

Erasmus, HJ (2015) "The beginnings of a mixed system, or, advocates at the Cape during the early nineteenth century, 1828-1850" Fundamina. A J of Legal History 21(2): 219-233

Eybers, GW (1918) Select Constitutional Documents Illustrating South African History 17951910 (London)

Farlam, Ian (2007) "The old authorities in South African practice" Tijdschrift voor Rechtsgeschiedenis 75: 399-408

Farley, Rawle (1955) "The economic circumstances of the British annexation of British Guiana (1795-1815)" Revista de Historia de América 39: 21-59

Fine, Hilton Basil (1991) The Administration of Criminal Justice at the Cape of Good Hope 17951828, 2 vols (DPhil thesis, University of Cape Town)

Fischer, DR (2006) “Grant, Sir William”, in Oxford Dictionary of National Biography (2006 online edition, accessed 2 Feb 2018)

Fletcher, Ian F (2005) Insolvency in Private International Law 2nd ed, available online at https:// www.insol.org (accessed Nov 2017)

Freund, William F (1989) “The Cape under the transitional governments, 1795-1814" in Richard Elphick \& Hermann Giliomee (eds) The Shaping of South African Society, 1652-1840 (Cape Town and London): 324-357

Glenn, Jane Matthews (2008) "Mixed jurisdictions in the Commonwealth Caribbean: Mixing, unmixing, remixing" J of Comparative Law 3: 53-76 


\section{A TALE OF TWO TRANSLATIONS}

Graham, David (2001) "Discovering Jabez Henry - Cross-border insolvency law in the 19th century” International Insolvency Review 10: 153-166

Graham, David (2005) "In search of Jabez Henry - Part II: The readership of Foreign Law" International Insolvency Review 14: 223-234

Graham, David (2006) "Henry, Jabez" in Dictionary of National Biography (2006 online ed, accessed 10 Nov 2017)

Hawke, Joanna (2006) "Horne, Thomas Hartwell”, in Dictionary of National Biography (2006 online ed, accessed 21 Nov 2017)

Hewett, Margaret (2000) "Old wine in new bottles, or: The story of translations of the 'old authorities' produced by South Africans" Pro Memorie. Bijdragen tot de Rechtsgeschiedenis der Nederlanden 2(1): 92-108

Hodgins, Thomas (1895) "The Judicial Committee of the Privy Council and colonial judges" Canadian L Times 15: 133-142

Howell, PA (1979) The Judicial Committee of the Privy Council, 1833-1876, Its Origins, Structure, and Development (Cambridge)

Kahn, Ellison (1985) "Solution to a mystery about the earliest South African law reports" SALJ 102: $187-190$

Keene, HG, revised by Roger T Stearn (2006) “Johnstone, Sir Alexander”, in Oxford Dictionary of National Biography (2006 online ed, accessed 21 Nov 2017)

Ledlie, JC (1917) "Roman-Dutch law in British Guiana and a West Indian Court of Appeal" J of the Society of Comparative Legislation NS 17: 210-222

Lee, RW (1914) "Roman-Dutch law in British Guiana" J of the Society of Comparative Legislation NS 14: 11-23

Lee, RW (1915) An Introduction to Roman-Dutch Law (Oxford)

Le Quesne, CT (1952) Book review (of Joseph Henry Smith Appeals to the Privy Council from the American Plantations) Modern LR 15: 382-386

Lloyd, ACG (1914) "The birth of printing in South Africa" The Library: A Quarterly Review of Bibliography and Library Lore 5: 31-43

Lorenzen, Ernest G (1934) "Story's Commentaries on the Conflict of Laws - One hundred years after" Harvard LR 48: 15-38

Murray, RW (1894) South African Reminiscences ... (Cape Town)

Nadaraja, T (1972) The Legal System of Ceylon in Its Historical Setting (Leiden)

Nadelmann, Kurt H (1961a) "An International Bankruptcy Code: New thoughts on an old idea" International and Commercial LQ 10: 70-82

Nadelmann, Kurt H (1961b) “Joseph Story's contribution to American conflicts law: A comment" American J of Legal History 5: 230-253

Oliver, VL (ed) (1914) Caribbeana, being Miscellaneous Papers Relating to the History, Genealogy, Topography, and Antiquities of the British West Indies vol 3 (London)

Renton, A Wood (1890) "Work of the West Indian commissioners III" Juridical Review 2: 357-365

Renton, A Wood (1932) "The Roman-Dutch law in Ceylon under the British regime" SALJ 49: 161-182 


\section{JP VAN NIEKERK AND GARDIOL VAN NIEKERK}

Roberts, AA (1942) A South African Legal Bibliography (Pretoria)

Rodway, James (1918) “The Press in British Guiana" Proceedings of the American Antiquarian Society 28(2): 274-290

Roos, J de V (1897) "The Plakkaat Books of the Cape" Cape LJ 14: 1-23

Roos, J de V (1906) "The statute law of the Cape in pre-British days, and some judicial decisions in relation thereto" SALJ 23: 242-254

Ross, Robert (1999) Status and Respectability in the Cape Colony 1750-1870. A Tragedy of Manners (Cambridge)

Sampson, Victor (1887) "Sources of Cape law" Cape LJ 4: 109-119

Smith, Anna H (1971) "South Africa" in Colin Clair (ed) The Spread of Printing: Eastern Hemisphere (Amsterdam) 1-171

Stander, GB (2000) Die Geskiedenis van Matie-Krieket 1865-2000 (MA, University of Stellenbosch)

Swinfen, David B (1987) Imperial Appeal. The Debate of the Appeal to the Privy Council, 18331986 (Manchester)

Stephen, Leslie, revised by Patrick Polden (2006) “Stephen, Henry John”, in Oxford Dictionary of National Biography (2006 online ed, accessed 7 Feb 2018)

Taitz, Jèrold Leonard, Ina Ackerman, \& Owen Barrow (eds) (1997) Juta Privy Council Reports (Cape Town)

Tambiah, HW (1972) Principles of Ceylon Law (Colombo)

Theal, George McCall (ed) (1897-1905) Records of the Cape Colony [RCC] 36 vols (Cape Town)

Van Boven, MW "Linden, Joannes van der" in Biografisch Woordenboek van Nederland 17801830, available at http://resources.huygens.knaw.nl (accessed 8 Nov 2017)

Van den Bergh, Rena (2012) "The remarkable survival of Roman-Dutch law in nineteenth-century South Africa" Fundamina. A J of Legal History 18(1): 71-91

Van der Burg, Martijn (2011) "De integratie van Kaap de Goede Hoop in het Britse rijk, ca 17951825" Pro Memorie. Bijdragen tot de Rechtsgeschiedenis der Nederlanden 13(2): 190-205

Van der Burg, Martijn (2015) "The age of revolutions at the Cape of Good Hope, 1780-1830: Contradictions and connections" J of Colonialism and Colonial History 16 (accessed from the Project MUSE database, 14 Aug 2018)

Van der Horst, Marleen HJ (1985) The Roman Dutch Law in Sri Lanka (Amsterdam)

Van der Merwe, PJ (1986) "Verwikkelinge gedurende die twintigerjare van die 19de eeu wat die Suid-Afrikaanse regswese beïnvloed het" Kronos 11: 37-66

Van Niekerk, Gardiol (2015) "Multilingualism in South African courts: The legislative regulation of language in the Cape during the nineteenth century" Fundamina. A J of Legal History 21(2): $372-392$

Van Zyl, DH (1983) Geskiedenis van die Romeins-Hollandse Reg (Durban)

Veen, Theo (2001) "Rechtsgeleerde boeken uit Zuid-Afrika" Pro Memorie. Bijdragen tot de Rechtsgeschiedenis der Nederlanden 3(2): 329

Visagie, GG (1954) Regsveranderinge aan die Kaap tussen 1823 en 1838 (MA thesis, University of Cape Town) 


\section{A TALE OF TWO TRANSLATIONS}

Waddams, SM (2006) “Lushington, Stephen” in Oxford Dictionary of National Biography (2006 online ed, accessed 6 Feb 2018)

Welsh, RS (1950) “The Privy Council Appeals Act, 1950” SALJ 67: 227-230

W[essels], JW (1907) "Notes on the history and development of the Roman-Dutch law (continued)" SALJ 24: 13-21

Wildenboer, Liezl (2015) "The Thirty-Three Articles and the application of law in the ZuidAfrikaansche Republiek" Fundamina. A J of Legal History 21(2): 457-476

Wilkinson, David (2006) “Adam, William” in Oxford Dictionary of National Biography (2006 online ed, accessed 6 Feb 2018)

\section{Case law}

Balston v Bird (1828) 1 Knapp 121, 12 ER 266

Craig v Shand (1830) 1 Knapp 253, 12 ER 315

Frankland v M'Gusty and Pearce (1830) 1 Knapp 274, 12 ER 324

Freyhaus v Cramer and Cantzlaar (1829) 1 Knapp 107, 12 ER 261

Nieuwerkerk $v$ Reynolds (1829) 1 Knapp 151, 12 ER 278

Odwin v Forbes (1817) 1 Buck 57 (PC)

President and Members of the Orphan Board v Van Reenen (1829) 1 Knapp 83, 12 ER 252

Simpson v Forrester and Bach (1829) 1 Knapp 231, 12 ER 306 


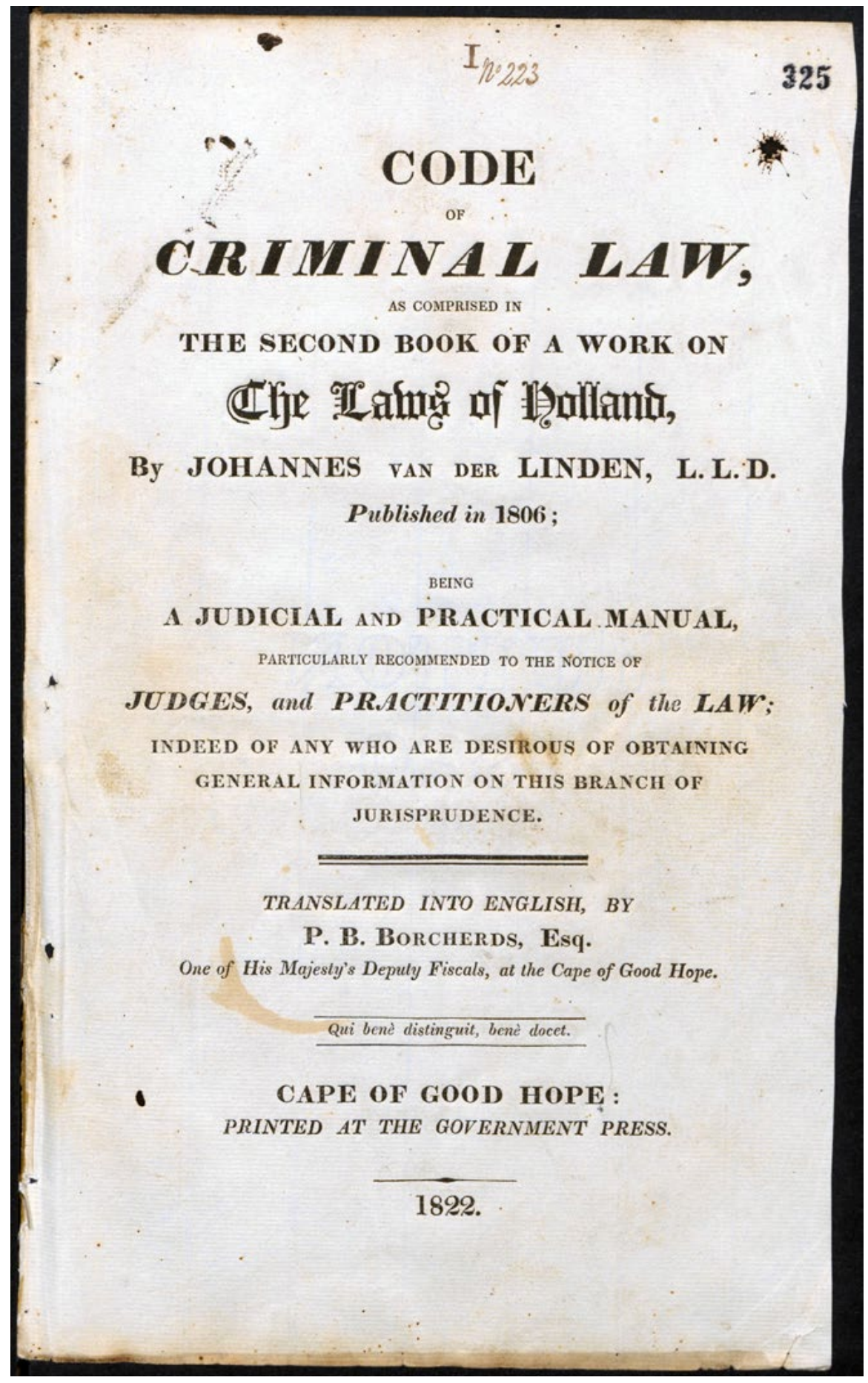




\title{
Lord CHARLES HENRY SOMERSET,
}

\author{
GOVERNOR AND COMMANDER IN CHIEF,
}

AT THE CAPE OF GOOD HOPE,

Whose anxiety for the general and individual Welfare, particularly of our New Colonists, has been lately so publicly expressed, this Translation of DR. VAN DER LINDEN's Treatise on the Criminal Law of Holland, is, with gratitude, most respectfully inscribed, by

His Lordship's most obedient, and

most humble Servant,

P. B. BORCHERDS. 


\section{PREFACE}

THE Motto in the Title Page, is justly applicable to Dr. Van der LINDEN's perspicuous Treatment of the whole Code of Dutch Law. My endeavour, in the present Translation of that part of his Work, relative to Criminal Jurisprudence, has been to give it an English Dress, in a manner, so far as my abilities would allow, clear and familiar; yet without departing from the genuine sense expressed by the Author, or giving any thing but what is truly Dutch Law.

I have used, therefore, a free rather than a strictly literal Translation, and have made some alteration in the arrangement of some particular heads and clauses, which, I think, if seen by the Author himself, he would approve.

The Translation, indeed, is intended chiefly for the use of my English Friends, (my Dutch ones can study it more satisfactorily in the Original,) many of whom are desirous, not only to be acquainted with what are the general principles of Criminal Procedure in the Dutch Law, but would like also to compare it with their own excellent and comprehensive National Work; and should they look for a happy coincidence in the general principles of distributive Justice, they will not be disappointed.

It is not to be expected, that, as a Foreigner, I should be so much a Master of the Niceties of the English Tongue, (however correct I may be found as to the general technical sense or meaning of the Law,) so as to translate it free from blemish, in many points of composition, as to style and other particulars: it is a duty, therefore, I have to acknowledge, that I have been greatly indebted to the aid of a particular Friend, in giving to the Work its last polish, its more easy and familiar style and character.

I send it forth, therefore, with the humble confidence, that it may not only be found useful, but divested in some measure, of that dryness or technical harshness, which so often attends Treatises on Law.

The revision of the whole has been afforded, by the kind indulgence of His Honor Sir JOHN TRUTER, who now presides at the head of the Law Department, in this Colony. His Name will be sufficient in recommendation of my little Work; and I am sure, I shall not be blamed for taking that advantage, which such distinguished aid is naturally calculated to produce. 


\title{
CONTENTS
}

\section{PART I \\ CODE of CRIMINAL JURISPRUDENCE}

\author{
CHAPTER I \\ OF CRIMES IN GENERAL
}

SECT. I

Of the division of Crimes

SECT. II

Of perfect and imperfect Crimes

CHAPTER II

OF GUILT IN ACTIONS

SECT. I

Of the Law Penal

SECT. II

Of voluntary criminal Acts

SECT. III

Criminal Acts, as they arise from neglect

SECT. IV

Those arising from chance or accident

SECT. V

Those committed by insane Persons

SECT. VI

Distinction to be made between Lunatics and those of imbecile Minds

SECT. VII

Acts committed by those of a melancholy Temperament

SECT. VIII

By deaf and dumb People 
JP VAN NIEKERK AND GARDIOL VAN NIEKERK

SECT. IX

Of criminal Acts, committed in a state of Drunkenness or Inebriety

SECT. X

Of Anger, as a plea in criminal Cases

SECT. XI

Of ignorance of the Law as a plea

SECT. XII

Of criminal Actions committed by those in a state of Infancy

SECT. XIII

The same relative to Minors

SECT. XIV

Of involuntary Crimes

CHAPTER III

OF ACCESSARIES OR ACCOMPLICES

SECT. I

Of aiding or abetting in general

SECT. II

On the commissioning of others, to execute a criminal intention, including the non-prevention and concealment of Crimes

SECT. III

Of estimating the degrees of atrocity in Crimes

PART II

OF PUNISHMENT

CHAPTER I

SECT. I

Definition of Punishment and its objects

SECT. II

Of the different kinds of Punishment 
BORCHERDS: VAN DER LINDEN'S CODE OF CRIMINAL LAW ....

SECT. III

Degrees of Punishment

SECT. IV

Rules for the application of Punishment

SECT. V

By what Laws Punishments should be inflicted

CHAPTER II

OF ARBITRARY PUNISHMENTS

SECT. I

Of altering, augmenting and mitigating Punishments

SECT. II

Reasons for the mitigation of Punishment

PART III

OF THE DISTINCTION OF CRIMES

\author{
CHAPTER I \\ OF CRIMES AGAINST RELIGION
}

SECT. I

Of Blasphemy

SECT. II

Of Perjury

CHAPTER II

OF CRIMES AGAINST THE STATE AND PUBLIC SAFETY

SECT. I

Of High Treason, or Crimen perduellionis

SECT. II

Of Lese-Majesty

SECT. III

Of counterfeiting Money 
JP VAN NIEKERK AND GARDIOL VAN NIEKERK

\author{
SECT. IV \\ Of public Violence
}

SECT. V

Of the different species of public and private Violence

SECT. VI

Of Arson

SECT. VII

Of Extortion and Bribery

CHAPTER III

OF CRIMES AGAINST THE LIFE, LIMB, AND REPUTATION OF OUR FELLOW-CREATURES

SECT. I

Of Homicide

SECT. II

Of Murder

SECT. III

Upon whom a Murder may be committed

SECT. IV

By whom a Murder may be committed

SECT. V

Of the qualifications relative to wilful premeditated Homicide or Murder

SECT. VI

Of Poisoning

SECT. VII

Of Parricide and Infanticide

SECT. VIII

The Law, with respect to mortally Wounding

SECT. IX

Of Suicide or Self-Murder 
BORCHERDS: VAN DER LINDEN'S CODE OF CRIMINAL LAW ....

SECT. X

Of Duelling

SECT. XI

Of excusable Homicide

SECT. XII

Of accidental Homicide

SECT. XIII

Of justifiable Homicide

SECT. XIV

Of the Punishment for Murder

SECT. XV

Punishment in particular, for Parricide and Infanticide

SECT. XVI

Crimes against the Honour or Reputation of our Fellow-Creatures

CHAPTER IV
OF CRIMES RELATING TO THE PROPERTY OF OTHERS

SECT. I

Of Theft

SECT. II

of Robbery

SECT. III

Of Frauds

SECT. IV

Of Peculation

SECT. V

Of Treachery, Chicanery, and Prevarication, among Practitioners of the Law

SECT. VI

Of Gaming, Cheating therein, and of Games of Hazard

SECT. VII

Of Bankruptcy 
JP VAN NIEKERK AND GARDIOL VAN NIEKERK

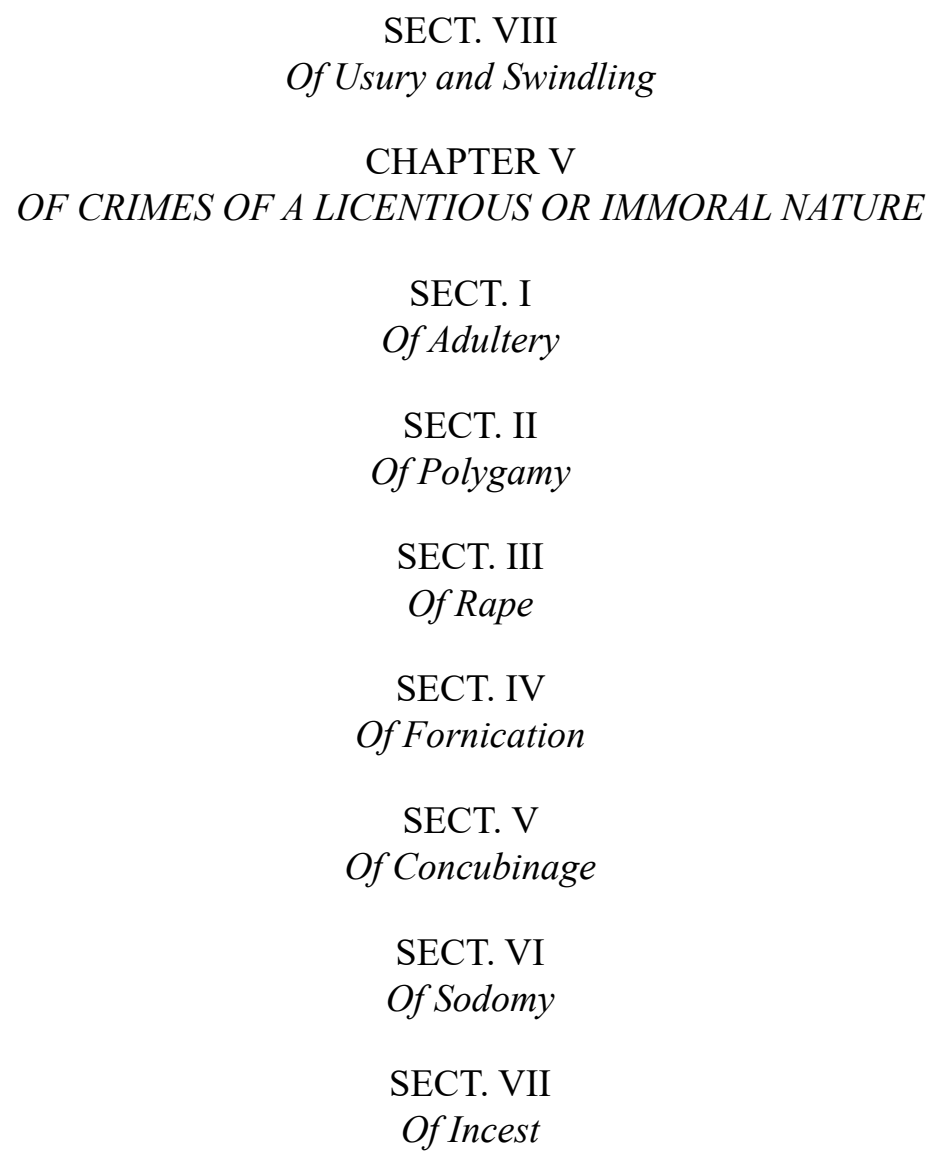

PART IV

THE LAW OF EVIDENCE, AND IN WHAT MANNER CRIMES MAY BECOME NULL OR EXTINCT

\author{
CHAPTER I \\ OF PROOF OR EVIDENCE IN GENERAL \\ SECT. I \\ Of the Corpus delicti \\ SECT. II \\ Of Confession \\ SECT. III \\ Of other species of Evidence
}


BORCHERDS: VAN DER LINDEN'S CODE OF CRIMINAL LAW ....

\author{
SECT. IV \\ Of Proof by indicia \\ SECT. V \\ Of written Evidence \\ CHAPTER II \\ IN WHAT MANNER CRIMES MAY BECOME NULL OR EXTINCT \\ SECT. I \\ By Punishment inflicted \\ SECT. II \\ By Pardon granted \\ SECT. III \\ By Composition and Submission \\ SECT. IV \\ By Prescription \\ SECT. V \\ By Death
}




\title{
JUDICIAL and PRACTICAL MANUAL, \&c. \&C.
}

\section{PART I \\ Code of Criminal Jurisprudence}

\author{
CHAPTER I \\ Of Crimes in general
}

\author{
SECT. I \\ Of the division of Crimes
}

By Crimes, (speaking of the Laws of one's Country,) are to be understood those voluntary and injurious acts, which are not only contrary to the Law, but to which, also, the State has affixed some penalty. Illegal acts committed through malice or design, are the most culpable: those through neglect or omission, less so; whilst those acts, which occur through misfortune or accident, cannot justly be imputed to the persons committing them, as Crimes. ${ }^{1}$

\section{SECT. II}

\section{Of perfect and imperfect Crimes}

In the commission of all Crimes, it ought to be considered, whether the perpetrator acted to the full extent of his intentions. Hence arises the distinction of Crimes into perfect and imperfect. With respect to those of the latter kind, it is further necessary to be considered, whether the Crime consist only in the intention of the Perpetrator, or whether this intention be already designated by some overt act; and, if so, the criminal extent of this act. ${ }^{2}$ It is also important to consider, whether the Perpetrator has persevered in his Crime by subsequent acts, and also, whether he has repeated the criminal act.

2 Boehmer, ad Const. Crim. Carol. ad Art. $131 \S 38$ \& Art. 178 §. 


\section{CHAPTER II \\ Of Guilt in Acts}

\section{SECT. I \\ Of the Law Penal}

Every act, deemed criminal, supposes a Law prescribing punishment for a commission of the same. Where this penalty is wanting, the act does not amount to a Crime, in the eye of the Law, though it may be a Crime severely punishable in other Countries. ${ }^{1}$

\section{SECT. II}

\section{Of voluntary criminal Acts}

The mere intention to commit a punishable act, does not constitute Crime. ${ }^{2}$ It must be designated or manifested by some overt act, and this clearly proved to have been committed. Simple suspicion will not do; and when the overt act, or acts, are clearly proved, it is then necessary to enquire, with what view they were committed; with what consciousness of their being criminal, ${ }^{3}$; for the consciousness of having committed Crime in what we have done, constitutes, in reality, the Guilt. ${ }^{4}$ Its being done voluntarily, is implied by the fact, the innocence of which, must be determined by other means. ${ }^{5}$ In determining the punishment necessary to be inflicted for the commission of a Crime, the different degrees of malice or neglect, discoverable in the intention of the person offending, are well to be considered by the Judge. ${ }^{6}$

\section{SECT. III}

\section{Criminal Acts, as they arise from neglect}

If a Crime appear to arise, more from a want of exercising a due judgment, attention, or discretion, than from the will or intention, it is then denominated a criminal neglect. If the Law inflict corporal or capital punishment for a Crime, a clear distinction should be made betwixt voluntary or wilful commission in the Crime, and mere neglect, ${ }^{7}$; for Crimes of neglect must never be punished by death, and seldom by the ordinary corporal punishment. ${ }^{8}$

1 Quistorp, §32.

2 L. $18 \mathrm{ff}$. de Poen.; L. $225 \mathrm{ff}$. de Verb. Sign.

3 L. 41 in fin. ff. ad Leg. Aquil.; L. 39; L. 53 pr. ff. de furt.; L. 79 ff. de Reg. Jur.

$4 \quad$ L. 4 § 1;L. 7 ff. ad Leg. Corn. de Sicar.; L. 1; L. 5 C. eod.

$5 \quad$ L. 1 C. ad Leg. Corn. de Sicar.; L. 5 C. de injur.

6 G. Fielangiri, Science de la Legislation Tom. 4 Chap. 14.

$7 \quad$ L. 4 § 1; L. 7 ff.; L. 1; L. 5 C. ad Leg. Corn. de Sicar.

8 Boehmer, ad Carpzovii, prax. Crimin. quaest. 27 obs. 1. 


\section{SECT. IV \\ Those arising from chance or accident}

If the act, neither originated in the design, nor imprudence of the perpetrator, but only fell out by chance, or unintentionally, it is then termed accidental: consequently, guilt will not be imputed to the person who committed it; nor can punishment, or legal requisition for indemnification ensue, or be demanded. ${ }^{1}$

\section{SECT. V \\ Of Acts, committed by insane Persons}

Acts, committed by persons extremely deficient in intellect, such as insane persons, or those deranged in their minds, or idiots, cannot be deemed criminal, and are, consequently, not punishable. ${ }^{2}$ It is the duty, however, of the Judge, when this deficiency is pleaded, to make every due enquiry, whether it exclude, in the perpetrator, all consciousness of crime in the act, and whether he may not possess, at intervals, moments of sane understanding; in order to determine, according to circumstances, whether punishment, ordinary or extraordinary, is to be inflicted. ${ }^{3}$

\section{SECT. VI}

\section{Distinction to be made between Lunatics, and those of imbecile Minds}

Distinction must be made betwixt Lunatics, or persons deranged in mind, and those merely of weak intellect, simpletons, or those childish in their acts, (acts, indeed, sometimes to be considered not less than Lunatic or idiotical, $)^{4}$ and who may be said to form a class betwixt infants and sensible men.

These can commit real crimes, and are persons upon whom corporal punishment may be inflicted, and even death, according to circumstances; for the act, constituting crime or guilt, does not depend so much upon a quick and penetrating mind, or perfect knowledge of the Law, as upon the consciousness of acting culpably and unlawfully. ${ }^{5}$ Nevertheless, there is a degree of simplicity, which, if properly proved, would form an important ground of defence, even in capital crimes, and principally in those founded upon neglect, or, in which the circumstances carry no appearance of particular wilfulness, or the liberation in the Agent. ${ }^{6}$

1 § 5 Inst.; L. 31; L. 51 ff. ad Leg. Aquil.; Boehmer, ad Const. Crimin. Carol. Art. 146.

2 L. 12 ff. ad Leg. Corn. de Sicar.; L. 13; L. 14 ff. de offic. Praesid.; L. 40 ff. de Reg. Jur.; L. 9 § 2 ff. ad Leg. Pomp. de parric.

3 Matthaeus, de Crim. in Proleg. Cap. 2 n. 6.

4 Quistorp, § 39.

5 Leyser, Med. ad Pand. Tom. 9 Spec. 599.

6 Leyser, d. 1.; Quistorp, §39. 


\section{SECT. VII \\ Acts, committed by those of a melancholy Disposition}

It is more difficult to determine, how far melancholic or low-spirited persons merit exculpation.

In general, much allowance cannot be made for such, if they possess the use of their senses, independently of their melancholy. There is, however, no doubt, that persons may, sometimes, be afflicted with such an extreme degree of melancholy and depression of spirits, as to be considered in the light of mad persons; and, in actions committed by them, when in this state, crime is hardly to be imputed; such persons, however, to prevent accident, are condemned to confinement. ${ }^{1}$ Such, moreover, are to be distinguished from those, who commit a crime from an aversion to life, upon whom the ordinary punishment should be inflicted. ${ }^{2}$

\section{SECT. VIII \\ By deaf and dumb People}

In the estimating of crime in acts, deafness and dumbness may become objects of consideration: that is, where such defects are innate, or originally deeply grounded, or seated, and there is reason to doubt the possibility of malicious design.

To prevent, however, the repetition of the injurious acts of such persons, they should be kept in safe durance for the remainder of their lives. If the culprit become deaf and dumb accidentally, and the maliciousness of the design be sufficiently apparent, he is then, in the eye of the Law, certainly amenable, and subject to punishment. ${ }^{3}$

\section{SECT. IX}

\section{Of criminal Acts, committed in a state of Drunkenness or Inebriety}

Drunkenness, being in itself a misdemeanour, especially in military men, ${ }^{4}$ cannot, therefore, strictly speaking, afford any ground of exculpation, for an offence committed by a person in that state. However, circumstances may exist, where the Judge is obliged to take the state of the man into consideration; and, herein, distinction is to be made, whether a person has voluntarily or unwillingly become intoxicated. If he has been enticed by others to drunkenness, it may sometimes form a plea in mitigation of punishment; but, if the culprit became intoxicated voluntarily,

1 Boehmer, ad Const. Crim. Carol. Art. 179 § 6; Carpzovii, prax. Crim. quaest. 145 ibique Boehmer, in observ. V. Hall \& Hamelsveld, Harmen Alfkens, Amsterdam, 1798.

2 Boehmer, ad Constit. Crim. Carol. Art. $137 \S 23$.

3 Carpzovii, prax. Crim. quaest. 147.

4 G. Feltman, Military Regulations, (Articul Brief,) Art. 67. 
in order to commit the crime more boldly, it cannot tend, in any degree, to exculpate him; but, on the contrary, to enhance his guilt. ${ }^{1}$

If Drunkenness, although voluntary on the part of the man, has occasioned in him a total mental derangement, and there be no appearance of a design to commit evil, but, on the contrary, the culprit afterwards exhibit every mark of repentance, then, sometimes, there may be room for granting a mitigation of the punishment prescribed for the offence. All this, however, depends upon circumstances, which may occur, more or less, in favour of the prisoner; for a Judge should not, in general, easily admit drunkenness as a ground of defence, or in extenuation of any criminal act, committed whilst in that state. ${ }^{2}$

\section{SECT. X \\ Of Anger, as a plea in criminal Cases}

The plea of anger, or great irritation of mind, cannot be admitted, unless there be circumstances of a very extenuating nature accompanying the act; as, should it appear, per example, that lawful reason for the offender's anger has been given, or, that he was not the author of the quarrel; if, immediately after the commission of the act, he show contrition, and a desire to make amends; if there be no appearance of a premeditated evil, or malicious design or intention; if he be a very young person; such circumstances may then be allowed to operate in mitigation of punishment. ${ }^{3}$

\section{SECT. XI \\ Of ignorance of the Law, as a plea}

If the culprit plead ignorance of the Law Penal, it is necessary to observe, whether the criminal character of the act he has committed, was not clearly apparent to every person, even to the most ignorant and uneducated; in which case, his pretended ignorance cannot be admitted as a plea. ${ }^{4}$ But if there be ground to suppose, that, on account of the unfrequent commission of the crime, or, for other reasons that might be adduced, the Law against it may not have reached his notice, then the Judge, upon the ground of such deficiency, may mitigate the punishment, but must not wholly remit it. ${ }^{5}$ This defence will be the more admissible, if the Law should be local, and the offending person a stranger, or foreigner; but, if he be an inhabitant of the Country, and the Law has been long and duly promulgated, and has not become obsolete, or

$1 \quad$ Leyser, Med. ad pand. Tom. 1 Spec. 59 Th. 3 \& Tom. 5 Spec. 348.

2 Carpzovii, prax. Crim. quaest. [146]; Quistorp, § 42[-]44.

3 Carpzovii, prax. Crim. quaest. 6, quaest. 18 No. 5 Seqq. quaest. 147 No. 41 Seqq. ibique Boehmer, in observ.

$4 \quad$ L. 2 C. de in jus voc.; L. 11 § 10.ff. ad Leg. Jul. de Adult.; L. 37 ff. de minor; $L .7$ C. unde vi.

5 Boehmer, ad Const. Crim. Carol. Art. $179 \S 12$. 
grown into disuse, the plea of ignorance is not admissible. ${ }^{1}$ It will also little avail the offender to urge, that, although he was not ignorant of such a Law existing, yet, that he did not consider it as applicable to his case; for such error, between the Law and the fact, cannot well exist; and if it does, it will be very evident, from circumstances, whether it can at all serve to exculpate him from the offence. ${ }^{2}$

\section{SECT. XII}

\section{Of criminal Acts, committed by those in a state of Infancy}

To Children, under seven years of age, crime, in acts contrary to the Law, are not to be imputed, as they cannot be supposed to have a due use of their reason, or understanding, ${ }^{3}$; and are, consequently, not liable to the ordinary public punishments, annexed to such acts, by the Law, in the manner that others are, ${ }^{4}$; but, in order to correct, or counteract any mischievous or malicious conduct in them, they are to be punished, but only by their Parents, Guardians, or Masters. ${ }^{5}$ If Children are above seven years of age, though not yet arrived at the age of puberty, or fourteen years, then, the punishment for inferior crimes, is left to the discretion of the Parents, \&c. ${ }^{6}$ But, if they commit any great crime, and there is ground to suppose in them, sufficient reason to discern between right and wrong, or, if they exhibit a wilfulness of design, superior to their age, then, instead of the ordinary public punishments being inflicted on them, they are punished with rods, by Police-men, (Geregts-dienaars,) or by imprisonment for a certain period, or by some other mode of correction, adapted to their age and condition. ${ }^{7}$

\section{SECT. XIII \\ Of the criminal Acts of Minors}

In Persons, above the age of fourteen years, but who are yet in their minority, this minority may be pleaded in mitigation of punishment, ${ }^{8}$ more particularly as relating to crimes of incontinence, and others of no serious consequence. But if it be an aggravated or atrocious species of crime; if it be often repeated; if the perpetrator be nearly of age; or, if there be ground to suppose in him malicious design, the plea of minority will be of little avail to him. ${ }^{9}$ But if, on the other hand, there be no absolute

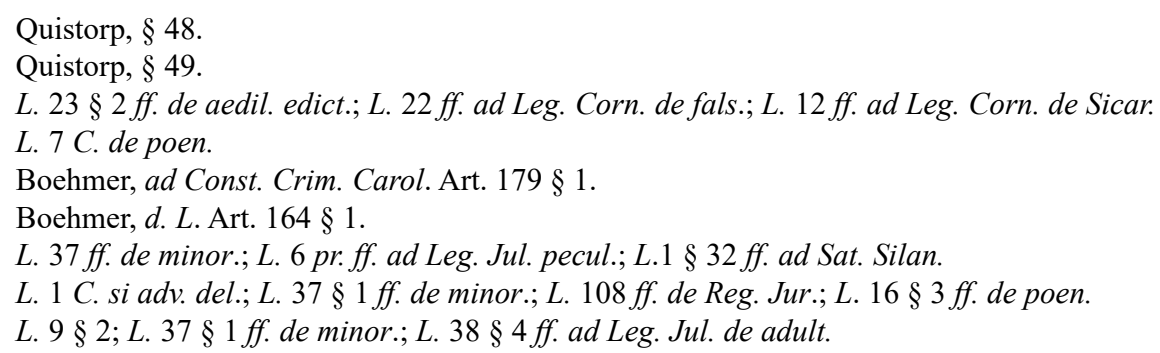


appearance of design, of malicious or criminal determination; if genuine contrition, or sincere repentance be shown; if the act be more the result of unruly passion, than cool and premeditated design or malice aforethought; if there be a sufficient prospect of amendment in future: in such cases, his minority may be allowed to stand him in some avail, in determining the degree of punishment to be inflicted; and even with respect to those crimes which are ordinarily subject to corporal or capital punishment. ${ }^{1}$

\section{SECT. XIV \\ Of involuntary Crimes}

As a free or voluntary intention to commit, constitutes crime in the agent, no offences can be considered as criminal, which are committed by persons in their sleep, or by those who are termed Sleepwalkers. ${ }^{2}$

\section{CHAPTER III \\ Of Accessaries or Accomplices}

\section{SECT. I \\ Of Aiding or Abetting, in general}

Those who are aiding or abetting crimes to the extent, that they would not have been committed without such co-operation, are named Accomplices.

If this participation in crime, is formed with an engagement or plan to execute certain criminal intentions, it is then called a conspiracy, and the actors in it a gang. If they are all in a situation mutually to aid, or assist, in the joint commission of a criminal act, or have acted as spies or sentries, to guard against detection, all are deemed equally guilty; although the act, (murder for instance,) may have been committed by some of them; unless such peculiar circumstances be exhibited, as to cause a difference in the application of punishment, that is, - should persons become accomplices through compulsion or timidity; or, if by different ${ }^{3}$ parties of the same gang, crimes of a different nature, unconnected and separate are committed at one period, each act is to be considered distinctly, although the perpetrators may be common parties in the general plot. ${ }^{4}$ If, again, the participation in the crime does not point out a conspiracy, but only a mere support in the criminal act, distinction must be made between those who directly aided or assisted in the crime, and those, who

$1 \quad$ L. $108 f f$. de Reg. Jur.; L. $16 \S 3$ ff. de poen.; Cocceji, exerc. curios. Tom. 2 Dispu. 41.

2 Boehmer, ad Const. Crim. Carol. Art. $179 \S 7$.

3 Boehmer, d. L. Art. $148 \S 1$; Quistorp, § 54.

4 Quistorp, d. L. in not. 
at the time of commission, or afterwards, are guilty of culpable acts, by which the perpetration of the crime is facilitated, or by which the crime committed is concealed. The first are considered as real accessaries, or accomplices, socii criminis, who are to be punished corporally or capitally, according to the nature of the offence; the others are called accessaries, (Anglice,) "after the fact," and are commonly less, or extraordinarily punishable. ${ }^{1}$

Further, with respect to this aiding or abetting crimes, the degree of participation ought to be accurately ascertained. - This is perfect or less so, and punishment is to be inflicted accordingly; to wit, if a person should furnish the instruments to commit a crime, the intention of doing which was known to him, although he may not he acting in the execution of the same, yet the participation is complete. ${ }^{2}$ Support, as before mentioned, may also be given after the commission of a crime, viz. by harbouring or concealing the perpetrator, or by sharing the profits acquired by the crime. $^{3}$

\section{SECT. II \\ Of the commissioning of others to execute a criminal intention, including the non-prevention, or concealment of Crimes}

A person may be particeps criminis, in commissioning others to execute crimes. In deciding, with respect to the degree of culpability in this matter, a few circumstances are to be taken into consideration, namely, whether, in commissioning others so to act, the mode of execution was prescribed; as also, whether the person so commissioned, was forced to obedience, or one subject to the power or authority of the person urging him to such commission. ${ }^{4}$

A person also, may be deemed particeps criminis, in advising another to the commission of a crime, and in this, likewise, there are circumstances to be taken into consideration, namely, whether the advice given was general, or stipulatory, relative to the manner of execution; whether the perpetrator had a previous intention to commit the crime, and afterwards received more encouragement from the advisor; or whether this advice gave the first inducement to commit the crime. ${ }^{5}$ Not preventing the perpetration of a crime, when in our power so to do, may afford just ground for punishment, particularly if it be proved that the opportunity of exercising this prevention was favourable, or dutiful. ${ }^{6}$

$1 \quad$ Boehmer, d. L. Art. $177 \S 1 \& 2$.

2 Quistorp, § 56.

$3 \quad$ L. 1 C. de his, qui latron; Boehmer, d. L. Art. 177 § 9; Quistorp, § 57 \& 58.

$4 \quad$ Boehmer, d. L. Art. 177 § 4; Putman, Opuscul. Jur. Crim. No. 1.

5 Quistorp, § 60.

6 Quistorp, $\S 61$. 
In short, it is evident from what has been stated, that a full view of the case, and all its concurrent circumstances, founded upon the general knowledge and experience of mankind, must be the Judge's chief guide, in estimating the guilt of the culprit. The concealment, also, of intended or projected crime, renders a man particeps criminis; this ought to be punished in an extraordinary manner. But, after the crime is committed, the keeping it a secret, is not punishable; unless, indeed, the welfare and safety of the State depends upon the disclosure, or an established Law, or official duty, requires it. ${ }^{1}$

\section{SECT. III \\ Of estimating the degree of atrocity, or guilt in Crimes}

In considering this, we are generally to be determined by the following Rules:-

1. The guilt becomes the more enhanced, by its being opposite to the higher obligations of our performing, or omitting to perform, some action. Upon this ground, the crime, by which the safety of the State becomes endangered, is greater than that, by which an individual only suffers. ${ }^{2}$

2. The more the crime is committed with deliberation, and a consciousness of guilt, the greater will be the atrocity. A repeated crime is, therefore, greater than one committed for the first time. The guilt, also, of a repeated crime, is increased, if the perpetrator has been before punished for the same. ${ }^{3}$

3. The more danger or injury also, there is attending the perpetration of a crime, the more flagitious it is. Upon this principle, a crime committed, is more atrocious, than if only attempted. The evil character, moreover, of a crime, is increased, if accompanied by other crimes.

By these Rules it is, that we may estimate the extent of the guilt, in crimes relative to accomplices. The guilt, therefore, in the accomplice of a conspiracy, is greater than when accidental, without previous deliberation, or agreement, or in one single instance. Actual aid and co-operation are more criminal, than simply counselling or advising; and the imputation of crime is less, as to the degree of guilt, if inducement be given by Parents, or others, to whom obedience is peculiarly or especially due. ${ }^{4}$

1 Boehmer, de obligatione ad revelandum occulta in Exercit. ad pand. Tom. 6 Exerc. 97.

2 Grotius, de J. B. ac P. Lib. 2 Cap. $20 \S 29$.

$3 \quad$ L. $28 \S 3 f f$. de poen.

$4 \quad$ L.157 pr. ff. de Reg. Jur.; Leyser, Medit. ad pand. Tom. 9 Spec. 580 Th. 8. 
PART II

\title{
Of Punishment
}

\author{
CHAPTER I \\ Of Punishment in general
}

\section{SECT. I \\ Definition of Punishment, and its objects}

By Punishment, is commonly meant, that pain or penalty, inflicted by the Supreme Authority in the State, upon any person, for not complying with the duties, or obeying the injunctions, imposed by that Authority.

The first great object of punishment is, the prevention of crime, by its producing that impression, which will deter others, as also the individual himself, from committing those injurious and illegal acts, which disturb the peace, safety, and welfare of the community. ${ }^{1}$

In punishments, not capital, there is another important principle to guide us, viz. the reformation of the individual himself; ${ }^{2}$ to which we may add, when possible, satisfaction or restitution, to the injured person or persons.

\section{SECT. II \\ Of the different kinds of Punishment}

These may be denominated severe and slight. In the higher or more aggravated species of crime, divided into capital and corporal punishments; and these last again, subdivided into simple, and those augmented by the necessity of additional severity. They may also be classed into ordinary, which are inflicted for all transgressions of the Law, which are of the same degree; and into extraordinary, which are adjudged according to the nature and degree of the guilt in the crime committed.

The different modes and degrees of punishment, as they relate to those of a corporal kind, including those which are capital, may be traced to the feudal times of darkness, ignorance, and superstition.

A sort of cruel and ferocious pleasure was then indulged in the infliction of punishment for crime. ${ }^{3}$ But the nearer we approach to more enlightened and improved times, when learning began to revive, and the mental faculties became consequently more enlarged, we find these cruelties proportionably disapproved of; and that [the] Judge was deemed to act most consistently with his character, whose awards, though sometimes necessarily severe, were yet without any mixture of cruelty. ${ }^{4}$

1 L.1 C. ad Leg. Jul. repetund.

2 L. $20 \mathrm{ff}$; L. 14 C. de poenis.

3 Heineccii, Elem. Jur. Germ. L. 2 Tit. 30; Putman, Elem. Jur. Crim. L. 1 C. 2 § 66 Seqq.

4 Seneca, de Ira Lib. 1 Cap. 5, 14, 15 \& 16, L.11 pr.ff. de poenis. 
The capital punishments which remain in force, are,

1. Breaking upon the wheel, with or without decapitation. $\dagger$

2. The gallows.

3. The sword.

4. Strangling, with or without scorching.

Quartering, burning, drowning, \&c. are not now in practice. That, also, of exposing dead bodies upon the wheel, or leaving them to hang on the gallows, to be consumed by the air, or devoured by birds, have been some years since, abolished. ${ }^{1}$

The corporal punishments, at present in force, are,

1. Scourging, with or without a rope round the neck, and with or without branding.

2. Confinement in a house of correction.

3. Condemnation to the public works.

4. Waving of the sword over the head.

5. Exposing upon the scaffold, with or without rods.

6. Praying for pardon, from God and their Judges, upon their bare knees.

7. Restriction for a certain time, to bread and water.

Punishments, which consist in maiming the limbs, have long been disused, as savouring of cruelty. There are only some few instances of piercing the tongue with a pin, cutting the face, and some others.

To these may be added, punishments, which, though not directly affecting the culprit's person, are yet thought proper to be inflicted.

To this belong,

1. Banishment for life, or for a certain term of years, from the Country, District, or Place. ${ }^{2}$

2. A denunciation of infamy.

3. Forfeiture of office or appointment.

Finally, it is no incompetent remedy, to punish the culprit in his means or property, by imposing the payment of great or small fines; and, if not paid within a certain time, to direct a proportionate corporal punishment to be inflicted upon him. ${ }^{3}$

1 Publ. Holl. 6th March, 1795. The Author here gives in consideration, whether it ought not to have been less limited.

2 Concerning the serious question, whether Judges in Holland can banish beyond their Territories, the Author refers to Bynkershoek, Quaest. Jur. Publ. L. 2 C. 17; V. D. Wall, Publications of Dordrecht V. 2 pag. 700 \& 701.

$3 \quad$ L. 1 § 3 ff. de poen.; L. 4 C. de Serv. fugit.; Gener. Ordonn. of Aug. 28, 1749, Art. 4, Public. March 2, 1751, and Jan. 23, 1753.

$\dagger \quad$ This punishment is no longer in use in this Colony, vide Appendix, Letter A. 


\section{SECT. III \\ Degrees of Punishment}

Although it be the duty of men and of christians, to banish from their tribunals every thing barbarous or cruel, yet, it would be absurd, to punish all crimes with the same corporal or capital punishments. ${ }^{1}$

Crimes admit of considerable degrees both of aggravation and alleviation; and this is well to be regarded in the application of punishment. For, it would be unreasonable, to punish murder and pure homicide or manslaughter, robbing on the highway, and petty larceny, with the same degree of punishment.

In former times, the capital punishment was augmented by the additional penalty of confiscation of goods; but since the year 1732, this is abolished by the laws, ${ }^{2}$ and very properly so; as all laws, by which the innocent suffer, as in the case of the delinquent's family and children, should be abrogated.

\section{SECT. IV \\ Rules for the application of Punishment}

It is a general maxim, that there should be no punishment without crime. -

A Judge, therefore, will do well to consider, in the first instance, every thing relative to the nature and degrees of crimes, as indeed we have above stated. Fully to apply the punishment directed by the Law, it is necessary that the crime should be wilfully committed. If the crime be not wholly, but only partially perpetrated, then the ordinary punishment by the Law for such crime, cannot be inflicted. ${ }^{3}$

Another maxim of Law is, that the punishment for crime can only affect the perpetrator, his accessaries, or accomplices ${ }^{4}$ consequently, parents are not punishable for the crimes of their children, - children for those of their parents, - nor masters for those of their servants, \&c.; unless they can be shewn to be participes criminis in any way. ${ }^{5}$

Heirs cannot be punished for the crimes of those to whose estates they succeed. ${ }^{6}$ They, however, will be made answerable for forfeited fines, and for those pending in Law, if the condemned should die before payment. ${ }^{7}$

1 This remark is of weight, against the introduction of the Guillotine; some delinquents were dressed in a red shirt, others not.

2 Resol. of Holl. May 1, 1732, Gr. Book of Placc. Vol. 6 pag. 577, V. 7 p. 844, and V. 9 p. 458, 459, $460 \& 462$.

3 Quistorp, § 83.

4 L. 22 C. de poenis.

5 Juridical Observ. of De Groot, part 1 observ. 75.

6 L. $26 f f$. de poen.

7 L. ult. C. si reus vel accus. mort. fuer. 
If a person have committed several crimes, consideration should be had, whether they are of a different or similar nature. On the first face of the matter it may appear, that the whole of the punishments for the different species of crime committed, should be inflicted so far as they can be combined in the execution: ${ }^{1}$ but it is customary in these cases, to use such additional severe corporal punishment, as may serve, as nearly as possible, to counterbalance all the different punishments. ${ }^{2}$ And if a person commit a crime subject to simple corporal punishment, and he afterwards perpetrate one of a capital nature, it is evident that the simple punishment merges in the more severe one; notwithstanding, to meet this, (viz: both crimes,) a capital punishment of the severer kind may be inflicted.

If a person, by the commission of several crimes, become subject to different punishments, which cannot be inflicted at one time, then the punishment for the crime that is most atrocious, should be inflicted; but no capital punishment can be inflicted in place of several corporal ones.

If the several crimes are of the same class, as to importance or degree, then, how far the Law awards peculiar punishments upon repeated crimes, should be attentively considered and followed; - if not, the ordinary punishment must be inflicted, which, where circumstances of an aggravated nature appear, may be somewhat increased. ${ }^{3}$ If the same crime be committed by several persons in concert, they form with regard to damages, (as our ancient Law expresses it,) one guilty person, (eenen baarschuldigen man.) ${ }^{4}$ But in the infliction of punishment, (if the participation in the crime causes no alteration,) each should be accountable only for his own actions in the peculiar share he may have had in the crime perpetrated. ${ }^{5}$

In crimes of great enormity, with respect to which, for the better preservation of the public peace and welfare, a general impression of abhorrence is to be produced, it has been customary to punish the perpetrator in effigy; ${ }^{6}$ but this, at present, is very seldom done. Something similar to this, is affixing the names of fugitive delinquents on the gallows, as a notice and warning to others. ${ }^{7}$ The execution of punishment upon the dead bodies of criminals, belongs to the barbarity of former times, and is no longer practised, than by burying them in some customary ignominious manner. ${ }^{8}$

1 Boehmer, ad Carpzovii, prax. Crim. quaest. 132 observ. 1.

2 L. 17 C. de poenis.

3 Quistorp, § 88-90.

4 De Groot's Intr. B. 3 part $34 \S 6$, Jurid. Observ. B. 2 observ. 89.

$5 \quad$ L. 22 C. de poen.; L. ult. ff. ad Leg. Corn. de Sicar.; Boehmer, ad Carpzovii, prax. Crim. part 1 quaest. 25 observ. 1 tom. 1 page 158.

6 Putman, Advers. Jur. lib. 1 cap. 14 lib. 2 cap. 25.

7 Feltman, Milit. Reg. page 255.

8 Boehmer, ad Carpzovii, prax. Crim. part 3 quaest. 131 observ. 3. 


\section{SECT. V \\ By what Laws Punishments should be inflicted}

In punishing crimes, the Laws of the place in which they have been committed should determine the sort of punishment to be inflicted; notwithstanding, the culprit may be elsewhere apprehended, and the proceedings against him should have been there instituted and carried on. ${ }^{1}$

The Law has prescribed punishment for almost every possible species of crime; but it has not determined, nor indeed well could prescribe, the punishment for one that has been partially committed; - that is, which has commenced, but has not been completed. This then must necessarily be left to the discretion of the Judge to determine, according to its progress and circumstances; and how far the attempts of the culprit have been effectuated, becomes a matter of consideration; and for this, so much of it as is made out by evidence, and in which the designs of the offender are rendered manifest, some adequate punishment of the extraordinary kind must be awarded. ${ }^{2}$

\section{CHAPTER II Of Arbitrary Punishments}

\section{SECT. I \\ Of altering, augmenting, and mitigating Punishment}

It is not allowable in the Judge to alter, augment, or mitigate the punishment which the Law prescribes for crimes, in cases where the evidence and circumstances which confirm the guilt, are complete, where nothing occurs to prevent the operation of the Law, and there can be no doubt of the propriety of the ordinary punishment being inflicted. The lawful grounds for discretion in the Judge, as to altering, augmenting, or mitigating the punishment, appear to be these: ${ }^{3}$

If the purposed end of the punishment established by Law, cannot be thereby obtained; if it be impossible, or at least very difficult, to inflict the prescribed punishment upon the person of the culprit; if the grounds of the Law, in application to the crime, are dubious or obscure; if the infliction of the punishment will, in any way, be injurious to others, who are wholly innocent persons; and if the peculiar situation or circumstances of the person render an exception as to the Law necessary: ${ }^{4}$ in such cases then, where the determination of the punishment is in a great measure left to

1 Voet, ad Tit.ff. de poen. No. 11.

2 Quistorp, § 96 and 97.

$3 \quad$ L. 11 pr.ff. de poenis; L. 15 C. eod.

4 Quistorp, § 99. 
the discretion of the Judge, and the crime to be adjudged is not of an aggravated nature; he is at liberty to alter the punishment according to the circumstances of the person or case, and direct a fine, or the like, in lieu of imprisonment, denouncement of infamy, and even corporal punishment. This discretionary power of the Judge, relative to the sort of punishment to be inflicted, as varying from the prescribed form in ordinary cases, takes place also when the Law does not appear sufficiently decisive as to the case; or when, from the nature of the evidence produced, it is doubtful whether the punishment prescribed by the Law for the crime is justly applicable. This power, thus vested in the Judge, is not, however, to be capriciously or incautiously exercised, - it has its bounds, which it must not exceed. ${ }^{1}$ The Judge must, therefore, observe in what manner similar crimes are, according to the laws and customs of other tribunals, generally punished.

Again, this discretion of the Judge is, for the most part, limited to corporal punishments, and cannot be extended to capital ones, notwithstanding the multifarious complexion of the crime, and other weighty reasons, might make it appear necessary to the welfare of the State, so to extend it. In all these cases, then, of a higher nature, it is requisite to make the matter known to the Legislature, upon whose authority the Judge will be better able to determine. ${ }^{2}$

\section{SECT. II}

\section{Reasons for the Mitigation of Punishment}

It will be necessary, likewise, to enquire into those reasons which may induce the Judge to mitigate the punishment; though they are generally supposed to exist in the consideration of the greater or less degree of moral guilt perceptible in the different cases, and the consequential injury. ${ }^{3}$ This mitigation of punishment is often found in a composition of a penal action by leave of the Judge, when the case is declared to be of a civil nature, and capable of compromise or commutation; or, in the culprit's submitting to the discretion of, and his being admitted to do so by, the Judge; on which subject, however, we shall have a better opportunity of treating hereafter.

Crimes cannot he compromised, except in cases of defamation and petty misdemeanors. ${ }^{4}$

Repentance for a crime intended to be committed, but only partially executed, or if witnessed immediately after the perpetration, may serve to shew an inferior or less malignant degree of design. Immediate reparation of damages, too, if accompanied by other favourable and alleviating circumstances, may afford ground

$1 \quad$ L. 78; L. 79; L. 80 ff. pro Socio.

2 Quistorp, $\S 100 \& 101$.

3 C. J. Heils, Judex et defensor in processu inquisit Cap. 6 pag. 335-546.

$4 \quad$ L. 36 ff. de dol. mal.; L. 39 ff. Sol. matr. 
for a mitigation of punishment. However, it should be well considered, whether this repentance may not be a pretended one, (galgen berouw,) and arising more from a dread of punishment, than real contrition for the wickedness of the offence, or the love of virtue, especially in great or completely perpetrated crimes. ${ }^{1}$

The old age of the culprit, (if it be not accompanied with a childishness, equal to insanity,) is in itself, no sufficient reason for the mitigation of punishment: for aged persons ought to calculate the moral nature and consequences of their actions, with more certainty and precision than young persons. However, in deciding upon the description and degree of punishment to be inflicted, great consideration is to be had, (particularly in corporal punishments,) to the age of the delinquent, and to the infirmity or debility that may be connected with it. Under this idea indeed, it often happens, that the severer punishment, by flogging, \&c. is commuted to confinement in a house of correction. ${ }^{2}$

Weakness in the female sex, is sometimes a motive for punishing women with less severity than men; unless they are guilty of a breach of the public peace and of open violence in their conduct; which, in women, carries with it a higher degree of moral offence. ${ }^{3}$

When a woman is declared to be in a state of pregnancy, no capital punishment can be inflicted on her, until after the birth has taken place, nor corporal punishment of any kind; which, in such case, is altered, if practicable, to some other mode of punishment. ${ }^{4}$

A bad education, and the incapacity it produces of judging of what is right or wrong, may tend to mitigate the punishment, if the crime be not of a very atrocious nature; if no aggravating circumstances be connected with it; and there are hopes of future amendment in the conduct of the individual. ${ }^{5}$

Previous good conduct, and where there may have been enticement to commit evil, by sufficient force or influence, and this clearly proved, - or by little design or premeditation being discoverable in the act, - are, in inferior cases, matters to be taken into consideration by the Judge. But if the person, thus wrought upon, be of age, and he continue giving way to seduction in the commission of crimes, he cannot, upon the plea of being influenced or enticed, be longer deemed innocent, or have further claims to indulgence. ${ }^{6}$

Illness of the culprit may suspend, but cannot do away, or make any alteration in, the punishment prescribed by the Law; unless the disorder be of such a nature that

1 Leyser, Medit. adff. T. 10 Spec. 645 Th. 7 and 8.

2 Boehmer, ad Capzovii, prax. Crim. part 3 quaest. 144 observ. 1.

3 Quistorp, § 108.

4 L. 3 ff. de poenis; L. 18 ff. de stat. hom.

5 Quistorp, § 109.

6 Quistorp, $\S 110$. 
corporal punishment could not be inflicted, without putting him in imminent danger of his life. ${ }^{1}$

The question, whether a long imprisonment is to afford ground for mitigation of punishment to the offender, cannot well be answered, without making a peculiar distinction of circumstances. If the imprisonment, not owing to the prisoner, has been unusually long, and the crime not capital, it not only affords ground for mitigation, but even, in crimes of a less nature, is often considered as partly, or wholly, in itself, of sufficient punishment: but in crimes meriting capital punishment, no length of time in the imprisonment can compound for the punishment being capital. ${ }^{2}$

There are other grounds to be offered, as affording room for the mitigation of punishment; such as the intercession made in favour of the culprit by the injured party; and the declaration, that the accused is a person of considerable talent and merit; that the greatest instigation to the commission of the crime was real poverty; that the offender has a large family of children; that he made a voluntary confession of his crime; that, though the time limited for the prosecution of the crime has not fully expired, yet a great length of time has elapsed since its commission; that the offended or injured party, had given the first cause of offence; with other similar reasons.

But, to whatever extent we may allow the above causes to be valid, it is clear that a strict regard should be paid to the nature of the crime, and to the concurrence of all its particular circumstances; and it is then, that the truth or fallacy of such reasons will be evident to a Judge of discernment, who will be able to decide accordingly. ${ }^{3}$

\section{PART III \\ Of the Distinctions of Crimes}

Having treated of Crimes in general, and their Punishments, we now proceed to examine the different Species of Crime. They may be classed systematically under the following heads: -

1. Crimes relative to Religion.

2. Crimes against the State or public Security.

3. Crimes against the Life, Limb, Honour, or Reputation of our Fellow Creatures.

4. Crimes against the Property of another.

5. Crimes of an Immoral or Licentious Nature.

1 Quistorp, § 111.

2 L. 25 ff.; L. 23 C. de poenis; Leyser, Medit. ad pand. tom. 10 spec. 645 th. 12; Boehmer, ad Carpzovii, prax. Crim. part 3 quaest. 149 obs. 2.

3 Quistorp, § 113-117b. 


\section{CHAPTER I \\ Of Crimes against Religion}

The farther we go back to the times of ignorance, superstition, and religious intolerance; of that bigotted zeal which guided the more formidable religious sects, - the greater and more extensive do we find this class of crimes, as cognizable by the Law, to be. ${ }^{1}$ But as mankind became more enlightened, and gradually emerged from a state of ignorance, superstition, bigotry, and intolerance, with respect to religious matters, declined; and the list of crimes, as they regarded religion, became proportionably diminished. The unhappy period, when heretics were persecuted by an inquisition, and the crime of witchcraft (so cruelly and absurdly charged upon the individual) was capitally punished by the Law, is past, and the like cases are at present not subject to judicial enquiry; unless, from the pretensions of those calling themselves conjurers or diviners, the public peace is likely to be influenced or disturbed; in which cases, there are sufficient grounds for a discretional correction by the Judge. ${ }^{2}$ Our Laws, at present, are in a manner limited to two species, - Blasphemy and Perjury.

\section{SECT. I}

\section{Of Blasphemy}

By Blasphemy is meant those words or actions, by which the Supreme Being (and we may include his Holy Word) is insulted and irreverenced. ${ }^{3}$ In this are included, the wilful propagation of the denial of his existence; the contemptuous attribution or assumption to God of acts contrary to his nature to perform; cursing also, and defaming the name of God; or ridiculing and disturbing his public Worship. It is evident, that this crime rests upon the degree of wilfulness in the insults offered, which varying in the degree of guilt or atrocity, may leave room, or not, for a mitigation of the punishment ordinarily denounced. ${ }^{4}$ The punishment inflicted for Blasphemy was formerly capital; and also some exemplary corporal punishment was inflicted, as piercing the tongue with a pin; ${ }^{5}$ but, in the present more tolerant and liberal times, this crime is punishable more in regard to its being considered as disturbing the public peace. It is a general rule now, therefore, to make the punishment for this crime discretionary in the Judge. It is usually punished by corporal punishment, fine, or imprisonment. ${ }^{6}$

1 Damhouder, Prax. Rer. Crim. Cap. 61.

2 Montesquieu, l'Esprit des Loix L. 11 Cap. 4.

3 Meister, Princ. Jur. Crim. § 433.

4 Quistorp, § 126 and 127.

5 Boehmer, ad Const. Crim. Carol. Art. 106.

6 Voet, ad Tit.ff. ad Leg. Jul. Majest. No. 1. 


\section{SECT. II \\ Of Perjury}

Perjury is the violation of the solemn oath, that we take before God in our appeal to him for the truth of what we say, or are about to say, or for the due performance of some act. If the duties to which we are bound by this oath are violated; or if to the prejudice of our fellow creatures, we declare upon oath that to be the truth, which we know to be false, - this is Perjury. The latter kind is certainly of a more aggravated nature than the former; and it is more or less so, according to the degree of malice, or self-interest exhibited in the design, as also, the degree of consequential injury attached to it. ${ }^{1}$

By our ancient Law, Perjury was punished by marking the face with a hot iron; ${ }^{2}$ and also, by cutting off the joint of the forefinger. ${ }^{3}$ But punishments, by which the body is maimed, are, at present, almost entirely disused; and scourging, confinement, banishment, \&c. have been substituted. ${ }^{4}$

Perjury is certainly a crime of a very atrocious nature, both as to the daring insult it offers to the Majesty of Heaven, and to the extensive injury it does to society; its wilfulness too is very apparent. The Judge, therefore, who neglects to visit this offence with a proper degree of severity, is certainly deficient in his duty, and very especially so, if he award a slight punishment.

\section{CHAPTER II \\ Of Crimes against the State, or Public Safety}

To this class of crimes belong High Treason, or Crimen Perduellionis; Lese-Majesty; Counterfeiting Money; Public Violence; Private Violence; Arson; Extortion; and Bribery.

\section{SECT. I \\ Of High Treason, or Crimen Perduellionis}

This crime is committed by those, who, with an inimical design, endeavour to subvert the State, or disturb its interests or independence, or endanger its safety; ${ }^{5} \mathrm{Eg}$. in their endeavour to bring it under foreign subjection; in treacherously surrendering of castles, towns, and other property of the State; in divulging its secrets with a disloyal,

1 Boehmer, ad Const. Crim. Carol. Art. 107.

2 Placc. of Zealand Cap. 4 Art. 11.

3 J. v. d. Eyck, Placc. of South Holland page 199.

4 Voet, ad Tit.ff. de Jurejur. No. 32 - (sentence of the Supreme Court, in the case of the Procurator General versus Marytje Blanken of Oct. 15th, 1756).

5 Boehmer, ad Const. Crim. Carol. Art. $124 \S 5$. 
rebellious intention; in favouring, by unjust privileges or advantages, the enemy in time of war, to the injury of the State; in inimically concealing the limits of the State. ${ }^{1}$ All may be guilty of high treason towards a State, even those temporarily residing in it. ${ }^{2}$ Every person acquainted with treasonable designs or practices, is bound to discover them, under certain penalties for not so doing; they are otherwise guilty of what is termed Misprision of Treason. ${ }^{3}$ The punishment for this crime is, for the most part, capital; the sort and manner of the execution being determined, according as circumstances may be more or less aggravated. ${ }^{4}$

\section{SECT. II \\ Of the Crime of Lese-Majesty}

The crime of Lese-Majesty, or where the dignity and honour of the Crown becomes affected or insulted, corresponds so far with High Treason, that it is shewn by acts tending to endanger the safety of the State; but differs in that it does not require the circumstance or presence of inimical design, which must always be the case with High Treason. ${ }^{5}$

It is clear, by this, that the crime is seldom punishable with death. The degree of punishment varies, nevertheless, according to the degree of culpable design apparent; a greater or less prejudice or injury consequent to the State; and the different relations in which the perpetrators may stand to the State, or society. Thus, the punishment may be either, waving the sword over the head, confinement, or banishment. ${ }^{6}$

\section{SECT. III \\ Of Counterfeiting Money}

This crime may be committed in various ways:-

1st. - By imitating the coin of the country; the counterfeit not bearing the real or intrinsic value.

2dly. - By diminishing the value of the true coin, by clipping, filing, or washing it with aqua fortis.

3 dly. - By coining money without legal authority so to do, although it may possess its intrinsic value.

1 Projects of the Criminal Code Ch. $2 \S 1$ Art. 1 and 2-20.

2 Voet, ad Tit.ff. ad Leg. Jul. Majest. No. 4.

3 Voet, ad L. T. No. 11; Boehmer, ad Carpzovii, Prax. Crim Part 1, Quaest. 41, Obs. 9.

4 Voet, ad L. T. 1 No. 6.

5 Boehmer, Elem. Jur. Crim. Cap. $5 \S 72$.

6 Quistorp, § 158. 
4thly. - By unlawfully transporting the money of the State out of the country, by melting it down, or breaking it. ${ }^{1}$

Accordingly, to the different species of this crime, (as more or less productive of injury to the State,) a punishment more or less serious may be inflicted. Coiners of base money, however, who have committed this crime in its most extensive bearing, are punishable with death. ${ }^{2}$

Those who are only guilty of clipping, or a less degree of falsifying, are punished corporally, or otherwise, as circumstances may direct. ${ }^{3}$

The counterfeiting of public notes, (or what is commonly called forgery, bonds, or obligations, redeemable annuities, receipts, \&c. is punished (and very equitably so) capitally, as for false coining, in consequence of the prejudicial results to the community in the transaction. If mitigating circumstances appear, corporal or some punishment extraordinary, is inflicted. ${ }^{4}$

\section{SECT. IV \\ Of Public Violence}

In the first and principal degree, the crime of Mutiny comes under this head. This is the application of violent or forcible means, by which the public peace and order are endangered, or the power of constituted Authorities and public Functionaries is attacked. ${ }^{5}$ As this crime exhibits itself in various sorts of acts, the punishment for it is made the more distinct and various, both in degree and manner. When of a kind very atrocious, the punishment of death is awarded. It is, however, generally punished by corporal punishment, imprisonment, or banishment. ${ }^{6}$ In times of public disturbance, when this crime is the more prevalent, the Government meets the evil, by enacting separate Laws, and providing punishments suitable to the exigency. Of this, during our own times, we are not deficient in examples. ${ }^{7}$ The ground of this crime, however, often lies in the various conceptions people may entertain, of what may be a just form of Government, - especially if the State have received a shock by recent revolution. In such case, there is no crime which more forcibly calls for due circumspection in the Judge; to the end that he may, on the one hand, pay every just attention to the preservation of peace and good order in the State; and on the other, be

$1 \quad$ Project of the Crim. Code Chap. 4.

2 L. 2 C. de Fals. Monet;; Voet, ad Tit. ff. ad Leg. Corn. de Fals. N. 8.

3 Voet, $a d$ D. T. No. 8.

$4 \quad$ Project of the Criminal Code Ch. 5.

5 Boehmer, ad Const. Crim. Carol. Art. $127 \S 1$.

6 Boehmer, D. L. § 3; Quistorp [§] 183.

7 Several Proclamations on this subject are to be seen in the Gr. Placc. Book, vol. 9 B. 3 \& 4, - to which may be added, Publ. of March 4th, 1795, March 1st, 1797, Nov. 4th, 1798, - and others. 
careful, lest by an unmeasured severity in the infliction of punishment for the crime, he make an unhappy sacrifice to the errors, prejudices, and misconceptions, which so commonly attend State divisions. $\dagger$

\section{SECT. V \\ Of the different Species of Public and Private Force or Violence}

Exclusive of exciting mutiny, the crime of using unlawful force attaches to all acts which are done to disturb the public peace and tranquillity, or where it is used in the encroachment on the rights, liberties, and property of others. ${ }^{1}$

In the more extensive sense, it is the practice to divide unlawful force into public and private; and to proportion the punishment in relation to the persons, upon whom the violence is committed; the circumstances of place, and the means employed. ${ }^{2}$ The nature of these offences is such, that no common and always adequate punishment can be prescribed; the sort and measure, therefore, must necessarily be arbitrary, and depend upon the discretion of the Judge, who will determine according to circumstances. ${ }^{3}$

In some cases, it is necessary to make the punishment capital; - such as robbing the mail. ${ }^{4}$ In many other cases, slight punishments, or corrections, will answer the end of justice.

We may comprehend, under the foregoing head, the liberation of a prisoner from confinement. The most aggravated species of offence in this particular, is, where the jailor or keeper of the prison wilfully liberates a prisoner of consequence, or who is in durance for high crimes; - in which case, even capital punishment may sometimes be inflicted. ${ }^{5}$ But if the liberation arises from inattention or neglect on the part of the jailor, then the punishment is discretional, varying according to circumstances. ${ }^{6}$ If the liberation be by the act of a third person, or more, (in which case it is commonly called a rescue,) regard is to be had, whether it was accompanied by tumult; whether any sort of violence or force was used; and of what nature; and accordingly, as circumstances are found more or less criminally aggravated, the punishment may be made more or less severe. ${ }^{7}$

If the prisoner have made his escape by his own means, then distinction is to be taken, whether he was imprisoned merely for safe custody, or for punishment. In

1 Matthaeus, de Crim. Lib. 48 Tit. 4 Cap. 1 No. 3.

2 Pothier, in Pand. Justin. ad Tit. ff. ad Leg. Jul. de vi Pub. \& Priv.

3 Groenewegen, de Legib. Abrog. ad § 8 lnst. de Pub. Jud.

4 Gener. Placc. 6th Dec. 1646, - in the Great Book of Placc. vol. 1 page 527.

5 Boehmer, ad Const. Crim. Carol. Art. $180 \S$ 1; Voet, ad Tit. ff. de Cust. \& Exhib. Reor. No. 8.

6 Leyser, Medit. ad Pand. Tom. 8 Spec. 564 Th. 8 Seqq.

7 Boehmer, ad D. Art. 180 § 4; Quistorp, § 193.

$\uparrow$ A wise, humane, and liberal caution. 
the first instance, correction must be awarded according to circumstances; - saving, however, the punishment for the crime for which he was committed. In the second case, the escape is also punished distinctly, - generally by prolonging the time of confinement, flogging with rods, \&c.; unless, indeed, any violence used by him in effecting his escape, should merit a more serious treatment. ${ }^{1}$

\section{SECT. VI}

\section{Of Arson}

Which is, where fire is designedly laid down near buildings, or other immoveable property, by which such property takes fire and damage is done thereby. ${ }^{2}$ In judging of the enormity of such an act, ${ }^{3}$ we are to observe, -

1st. - The extent of the danger; as where a whole town, for instance, becomes endangered. In this case, the crime is of a more aggravated nature, than if fire is laid merely to some solitary or remote building.

$2 \mathrm{~d}$. - The design of the incendiary is to be considered, though the result may not be commensurate with the wicked intention.

3d. - Aggravating circumstances; such as, if the setting on fire was done with a murderous intent, or fire-murder, (moord brand, an ancient Law,) or for the sake of plunder, ${ }^{4}$ the crime is then greater than if committed simply from a principle of revenge, or with a view to create damage to the premises only.

The punishment for wilful incendiaries is, in our country, Death. The culprits are usually strangled and scorched; or, under aggravating circumstances, burnt alive. ${ }^{5}$ If a person occasion a fire through negligence, it does not come under the crime of Arson; but some punishment is awarded, according to the degree of incautiousness or neglect, over and above his being obliged to compensate for the damage sustained by the owner, through his carelessness. ${ }^{6}$

\section{SECT. VII \\ Of Extortion and Bribery}

Extortion is where a person from interested motives, taking undue advantage of his situation, or power over another, compels him, often by threatenings, to consent

1 Voet, ad D. Tit. ff. N. 9; Quistorp, § 194.

2 Quistorp, § 196.

3 Boehmer, ad Const. Crim. Carol. Art. 125.

4 V. d. Wall, Regul. of Dordrecht 1st vol. page 202, Regul. of Vlaardingen page 36.

5 Voet, ad Tit.ff. de Incend. [Ruin.] Naufr. N. 5.

6 Quistorp, § 203 and 204. 
to what he wishes. ${ }^{1}$ Such are among the worst pests of civil society, and merit the severest correction. The punishment for this crime is discretionary. There must be restitution made of the property extorted, besides the loss of their situations, - fine or imprisonment, \&c. ${ }^{2}$ Several Laws have been enacted against military extortion. ${ }^{3}$

Bribery by Public Functionaries, is, when by unlawful and prohibited means, they endeavour to obtain dignified or advantageous situations. Many with us, who are appointed to such situations, are previously obliged to take the oath against Bribery and Corruption, (Eed van Zuivering, $)^{4}$ with this additional clause, "that they will act hereafter with clean hands;" that they will, in the execution of their office, not be bribed by gifts or presents; - if they transgress their oath, they incur the usual penalties of perjury.

\section{CHAPTER III \\ Of Crimes against the Life, Limb, and Reputation of our Fellow Creatures}

SECT. I

Of Homicide

$\uparrow$ Homicide is the act of taking away the life of any rational being. Homicide, in its legal acceptation, is divided into justifiable, excusable, and felonious. Of felonious, the worst is that which constitutes Murder.

\section{SECT. II \\ Of Murder}

$\$$ Murder, then, is that act by which a fellow-creature is unlawfully deprived of his life, through the wilful design of another. With respect to this crime, there are several material points of consideration, which we shall inquire into, in their due order.

*To constitute murder, it is requisite,

1. That a person is killed or mortally wounded.

2. That it is committed with malice prepense, - a wilful and premeditated design.

1 Futman, Elem. Jur. Crim. $\$ 194$.

2 Meister, Princ. Jur. Crimin. § 2 part 2 cap. $19 \S 222-225$.

3 Voet, ad Tit.ff. de Concuss. N. ult. in fin.

4 Voet, ad Tit.ff. de Leg. Jul. Ambit.

$+\quad$ Translator's Note.

\$ Vide orig. § 1 .

* Vide orig. $\$ 10$. 
3. That the perpetrator had either a view to obtain some profit or advantage by it, ${ }^{1}$ or was thereto excited by a spirit of hatred or revenge.

The punishment for this crime is every where capital, (formerly the wheel.) ${ }^{2}$

$\dagger$ The enormity of murder depends upon a greater or less degree of premeditation in the act; upon a clear knowledge of the heinousness of the crime, and its consequences; upon the relation in which the murdered stands to the murderer; upon the base and wicked object the murderer had in view, when he perpetrated the deed; and upon those promotive causes of reason and humanity, which, upon due reflection given, could, and ought to have deterred him from the commission of the crime.

\section{SECT. III}

\section{Upon whom Murder may be committed}

$\ddagger$ It may be committed upon all living and rational beings, without distinction of age or sex; ${ }^{3}$ also, upon those that are sick, though there be no hopes of recovery. ${ }^{4}$ Upon what are termed monsters, or mis-shapen conformations, brought into the world, no murder can be committed. It is, indeed, customary to smother them, but not without the consent of some superior authority. ${ }^{5}$ We may commit murder, too, on the mad or insane; upon notorious villains, heretics, \&c. ${ }^{6}$ It is sufficient according to our definition, if we take the life of any fellow creature, in an unlawful, or unjustifiable way.

\section{SECT. IV \\ By whom Murder may be committed}

*By all persons found to have occasioned the unnatural or violent death of another; although, in a literal sense, he did not commit himself any actual violence. ${ }^{7}$ Thus, a murder is committed, if we cause a person's death by depriving him of the necessaries of life; and generally, if any illegal act be the immediate cause of death, it is deemed murder in the person having so caused it.

$1 \quad$ Boehmer, Elem. Jur. Crim. § 2 cap. 17.

2 S. van Leeuwen, Cens. For. part 1 lib. 5 cap. 12 and 13.

$3 \quad$ L. 1 § 2 ff. ad Leg. Corn. de Sicar.; Leyser, Medit. ad Pand. tom. 9 spec. 597 th. 5.

4 Boehmer, ad Const. Crim. Carol. art. $137 \S 2$.

5 De Groot's Introd. b. 1 ch. 3 § 5, Jurid. Observ. ch. 1 observ. 7.

6 Boehmer, d. L.

7 Boehmer, ad d. art. § 1.

$+\quad$ Qrigin. § 5 .

$\star \quad$ Origin. § 2 .

$* \quad$ Origin. $\$ 3$. 


\section{SECT. V}

\section{Of the Qualifications relative to wilful premeditated Homicide, or Murder}

$\dagger$ Wilful Homicide or Murder may be differently qualified. The place where, and the time when, are often matters of serious import. The appearance, also, of the murdered person, and the cruel manner in which the murder shews itself to have been committed, are points of serious consideration; the malice prepense with which the act appears to have been committed, \&c. ${ }^{1}$

The malicious design in Homicide is considered to be proved, when a person resolving to commit the crime, shews his intention, by his manner of execution, and other circumstances. Where violent attacks, for instance, are made by him upon a person during the night season, or in the dark; where repeated blows are given by him upon dangerous parts of the body, which cause death; when the whole collected conduct of the Homicide, or Murderer, bears proof of his malicious intentions to kill; especially when his attempts are aimed at the head, or any other very vulnerable part of the body.

Yet, to establish a murder, at least to incur its penalty, a direct intention is not always necessary to be proved; an indirect design is sufficient: as in the case where a person has unlawfully attacked another, viz: with a dangerous weapon, and with a view only to wound him, and that wound, however contrary to the inflictor's design, should occasion death. ${ }^{2}$

\section{SECT. VI \\ Of Poisoning}

Poisoning is a very aggravated species of murder. By it, we understand all such administrations of drugs, \&c. which may affect the life of another. But a wilfulness to deprive a Person of health or life by it, must be shewn in the act. ${ }^{3}$ The punishment is capital; and usually, on account of the ensnaring subtlety and artfulness displayed in this abominable species of murder, it meets with the severer kind of death; such as breaking alive on the wheel. ${ }^{4}$

However enormous the attempt to commit this crime may be, yet mitigating circumstances may sometimes attend it. If by giving assistance, the mortal effects

1 Quistorp, § 221.

2 Boehmer, ad Const. Crim. Carol. art. 137 § 4-7.

3 Leyser, Medit. ad Pand. tom. 9 spect. 609.

4 Boehmer, ad Const. Crim. Carol. art. 130; Voet, ad tit. ff. ad Leg. Corn. de Sicar. N. 14. Vide Appendix, letter A.

$\dagger \quad$ Origin. $\S 5$ part 2. 
of the poison are prevented; if the poison should be prepared by him, but not yet administered, \&c. ${ }^{1}$

\section{SECT. VII \\ Of Parricide and Infanticide}

$\dagger$ In times even the most remote and barbarous, Parricide and Infanticide were deemed peculiarly horrid crimes. In an extended view, the murder of relations is included under the term Parricide, which relationship always aggravates. ${ }^{2}$ To establish the crime of Infanticide, it is necessary that the child killed was born alive, and full grown; and this must be determined by the apparent evidential marks. ${ }^{3}$ Great weight, (where there is any suspicion of murder having been committed on the body of a child), has been attached to an experiment, to ascertain the fact of its having been born alive or not: the lungs are thrown into water; if they sink, the child is accounted to have been born dead; if they swim, or float on the surface of the water, the child must have breathed, and have been born alive. With all this, however, although the experiment may form a ground for exculpation, yet it is of too uncertain and indecisive a nature to form one, (unattended with other strongly corroborating circumstances,) for accusation and condemnation. ${ }^{4}$

Besides the direct killing of a child, the crime may be committed through wilful neglect; - such as not purifying the child, but suffering it to smother in its own dirt; by withholding nourishment from it; by not tying up, (or rightly breaking or dividing) the navel string, \&c. ${ }^{5}$

Infanticide may be committed not only upon children already born, but with respect to those also in the mother's womb; as in the case where a living birth is prevented by any violent means having been made use of to procure abortion. ${ }^{6}$

To this crime also belongs the dangerous exposure of children as foundlings. If this be done with a view that they should perish, it is murder. When the child dies under the exposure, without any such design being manifested, it comes under the head of culpable homicide. ${ }^{7}$

1 Quistorp, § 264-266.

2 Boehmer, ad Const. Crim. Carol. art. $131 \S 1$ and 2.

3 Boehmer, ad d. art. $131 \S 3$.

4 P. Camper on the Signs of Life and Death in New-born Children [(Leeuw, 1774)].

5 Boehmer, ad Carpzovii, prax. Crim. part 1 quaest. 9 obs 5.

6 Boehmer, ad Const. Crim. Carol. art. 133.

7 Boehmer, d. l. art. 132.

$\dagger \quad$ Origin. $\S 12$. 


\section{SECT. VIII \\ The Law with respect to Mortally Wounding}

$\dagger$ In a murder, or violent death, this is the great leading distinction, - that the wounds or bruises are the true and only cause of the subsequent death; and not merely that they contributed to terminate life. ${ }^{1}$ Nor is the mortality of the wound to be determined by the nature of the instrument employed; a blow with the fist may inflict a mortal wound; ${ }^{2}$ but it depends in these cases, upon the manner of wounding, and the place where the wound, $\& \mathrm{c}$. is given. ${ }^{3}$

If any person whatever, or a person of the same constitution as the one killed, would, according to the usual course of nature, have died of the wounds, then it is absolutely mortal, and the perpetrator is guilty of murder. If the wound be but accidentally mortal, or presumed so to be, viz: not absolutely by its nature, but by consecutive circumstances; then, inquiry is to be made, how the case actually stands; as, whether death was owing to an effusion of blood, fever, convulsions, gangrene, and similar incidents, not occasioned by any wilful or perverse conduct on the part of the wounded, - it will then exculpate the inflictor of the wound from the charge of murder; but only, if such accident be occasioned by some wilful or imprudent conduct on the part of the wounded person, whereby the wound, which was not absolutely mortal, becomes so, and the person dies. ${ }^{4}$

That the person should live some days after the infliction of the wound, (some say nine,) does not make the wound accidentally mortal; but it may amount, with other concurrent circumstances, to a probability that the wound gave rise to the person's death, though it did not absolutely, or solely, cause it. ${ }^{5}$

$\$$ Wounds not mortal are punishable in the inflictors, in various places, by various regulations. In many towns and villages, by pecuniary fines, ${ }^{6}$ over and above the payment of legal damages. So far as those wounds are attended with aggravating circumstances, and can be brought under the charge of violence, it may afford ground for the infliction of more or less punishment of the arbitrary kind, or at the discretion of the Judge.

$1 \quad$ Quistorp, § 219.

$2 \quad$ L. 7 § 1 LL. $27 \S 23$ ff. ad Leg. Aquil.

3 Upon absolute and accidental Mortal Wounds, see the Writers on Medicina Forensis, viz: Ludwig, Hebenstreit, Plenck, Schlegel, and others.

4 Quistorp, §220.

5 De Groot's Introduction 3 b. ch. 34 8, Jurid. Obs. 1 ch. obs 93.

$6 \quad$ S. van Leeuwen, R. Dutch law b. 4 ch. 35 No. 2 and 3.

$\dagger \quad$ Orig. $\S 4$.

$+\quad$ Orig. $\S 15$ page 1 . 


\section{SECT. IX \\ Of Suicide, or Self-Murder}

$\uparrow$ Although Suicide be indubitably an unjustifiable act, ${ }^{1}$ yet it does not, at present, in the eye of the Law, come under that class of wrongs, which are to be vindicated by public punishment. ${ }^{2}$ By an ancient custom of this country, (Holland,) the bodies of those that committed suicide were directed to be dragged upon a sledge to a gibbet, and there hung, and their goods to be confiscated; but this custom is now in disuse. ${ }^{3}$ They are only buried quietly, and without any ceremony being used.

\section{SECT. X \\ Of Duelling}

†With respect to Duels, several laws have been enacted ${ }^{4}$ and in particular, a placcaat of the States of Holland, of the date of the $22 \mathrm{~d}$ of March, 1657, thus determines: ${ }^{5}$ It says briefly: -

1. That no person shall call out another to fight a duel, or being called upon, shall go, under penalty of forfeiting his office, or situation, and being subject to fine.

2. That the bearers of the challenge, and seconds to the parties, shall be liable to the same punishment.

3. That every person acquainted with a challenge is bound to give information thereof.

4. That they who actually fight a duel and survive, and their seconds, shall be banished out of Holland for six years.

5. That the body of a person killed in a duel shall be buried in the evening, or at night, without any attendance.

6. That if the person killed shall have been the challenger, then the body shall be exposed.

1 T. [Dumas], Traité $d u$ Suicide Amst. 1773.

2 Concerning the Causes of Suicide, reference is made to L. Avenbrugger on Internal Insanity, or the Desire to commit Suicide, considered actually as a Malady: printed in Dordrecht 1788.

3 De Groot's Introd. b. 2 ch. $1 \S 44$, Jurid. Observ. ch. 2 observ. 23.

4 Placc. July 1st, 1637, Gr. Placc. B. 2 vol. col. 458; Placc. May 20th, 1641, Gr. Placc. B. vol. 1 col. 391; Placc. March 31st, 1684, Gr. Placc. B. vol. 4 page 162.

5 Gr. Placc. B. vol. 2 col. 459.

$\dagger \quad$ Orig. $\S 14$.

$+\quad$ Orig. $\S 15$ page 2 . 
7. That he who has killed another in a duel shall be punished with death; and that no pardon, or remission of the punishment, shall in anywise be granted him.

\section{SECT. XI \\ Of Excusable Homicide}

\{What is here meant by the word excusable, is, that the person so acting is not excusable in foro conscientiae, at all times, or in a moral view; but rather, that the Law considers him as excusable, at least of any murderous intention; and though such species of homicide be not subject to capital punishment, yet it attaches some degree of culpability to the person committing it.\}

$\dagger$ This species of Homicide may be committed where there is no direct intention either to kill or wound, but where the act done causes death, which, with sufficient care and caution might have been avoided. ${ }^{1}$ If, for instance, in doing certain work, a person acts so incautiously that he causes the death of another. ${ }^{2}$ When, again, wild animals are kept carelessly confined, which are accustomed to kill, bite, or devour. ${ }^{3}$ When also, in play, blows are given which cause death; or in bestowing correction, the bounds of moderation are exceeded, and thereby homicide ensues. When a person, moreover, is killed by another imprudently throwing, or cutting down, something. When, though attacked unlawfully, the bounds of that defence which is necessary for protection, are exceeded, and death ensues. ${ }^{4}$ When a person, without having given cause or provocation for it, is insulted by another, and this gives vent, in the person so insulted, to immoderate rage and passion, which causes him to commit homicide.

Generally, the crime of what is called Excusable Homicide comes under this idea, that a person might have calculated that his act would deprive another of his health or life, and consequently attaches some degree or other of culpability to him.

Although that incautiousness which causes the violent death of another, differs considerably in degree of culpability, and therefore, in one case may be more punishable than in another; yet, the homicides which are caused by any degree of it, are so far of an excusable nature, as never to be considered punishable to the extent that wilful homicides are, and consequently, never visited with the ultimum supplicium (punished with death). ${ }^{5}$

1 Quistorp, $\S 6$.

2 L. 31 ff. ad Leg. Aquil.

3 Boehmer, ad Const. Crim. Carol. art. 136.

4 Boehmer, d. l. art. 142.

5 Quistorp, $d$. $\S 224$.

$\dagger \quad$ Orig. $\S 6$. 


\section{SECT. XII \\ Of Accidental Homicide}

$\dagger$ By Accidental Homicide is understood those cases which originate, neither in the wilfulness, neglect, nor incautiousness, of the perpetrator or agent; and yet, contrary to what was expected, the act has caused the death of another. Such are inculpable acts, but they are rare; for mostly, some degree or other of incautiousness or neglect, may be traced in the act. ${ }^{1}$

\section{SECT. XIII \\ Of Justifiable Homicide}

$\$$ A principle of defence will, in many cases, render a homicide justifiable; that is, where a homicide takes place in defence of one's life or person; but then, it must he admitted as justifiable, on the following conditions only: -

1. Where there is an unexpected and unjust attack.

2. A clearly existing danger, that the defender may lose his life by such attack.

3. The impossibility of saving his own life, but by taking that of the aggressor. ${ }^{2}$ The defence merely of one's honour gives no ground to commit homicide, upon a principle of self-defence, unless, perhaps, in persons who, in their peculiar situation of life, would by flight ruin themselves. ${ }^{3}$

There is certainly one exception, on the ground of honour, to the above rule. If a woman, for instance, find no other means of defending her honour, or virtue, against the assaults of a ravisher, than by killing him, she would certainly be justified in so doing. ${ }^{4}$

Defence of one's property against a thief, or robber, may sometimes be admitted as a plea for the homicide in killing the thief, being considered of a justifiable nature; that is, if he could not be prevented in any other manner. ${ }^{5}$ But in these cases, we must be guided very much by circumstances; and it behoves us to consider, whether the case does or does not come under that class of acts, which we have before termed excusable, though culpable, homicide.

The necessary sort of defence which will justify homicide, is not confined to the preservation of a person's own life; but extends also to the life, honour, and property of his children, wife, relations, friends; indeed to every person who is unjustly and dangerously attacked. ${ }^{6}$

1 Boehmer, ad Const. Crim. Carol. art. 146.

2 Boehmer, ad Const. Crim. Carol. art. 140.

3 Leyser, Medit. ad Pand. tom. 9 spec. 600 th. 22.

4 Putman, Elem. Jur. Crim. § 320.

5 Putman, d. l. § 321.

6 Boehmer, ad Const. Crim. Carol. art. $150 \S 1$.

$\dagger \quad$ Orig. $\$ 7$.

$+\quad$ Orig. § 9 . 
As all murder carries the presumption of a wilful intention in the commission of it, if the person who is presumed to be guilty thereof, should allege necessary personal defence in the commission, as the cause, he must, either by direct evidence, or at least by proofs deduced from the circumstances of the case, shew that he comes under that species of homicide in the act, which the Law considers as justifiable. ${ }^{1}$

\section{SECT. XIV \\ Of the Punishment for Murder}

$\dagger$ The punishment for this crime, according to all Laws, both human and Divine, if wilfully committed, is death; ${ }^{2}$ the kind varying according to the aggravating or extenuating circumstances accompanying the commission of the deed. If wilful homicide be effected by a combination of persons, who made a common engagement to perpetrate the murder, and co-operated in the same, they all must suffer death. ${ }^{[3]}$

If a murder be committed in the presence of different persons, who were all participators in the quarrel which gave rise to it, then only the person who gave the mortal wound is the murderer, and to be punished with death. The rest are punished arbitrarily, or discretionally. This last mode must be resorted to, where a death has happened, and it cannot be ascertained who the person was that inflicted the mortal wound. ${ }^{4}$

The reasons for mitigation of punishment, in cases of homicide of the different species, are easily collected from the principles of Law as above given. ${ }^{5}$

With respect to murder, it may be added, that persons of skill differ sometimes a good deal with regard to the mortality of wounds, where death has ensued some time after the wounds have been inflicted, - so as to occasion some doubt, whether the wounds were the sole cause of the person's death, or not $;{ }^{6}$ and consequently, whether the punishment is to be considered capital or not.

Homicide occasioned by neglect or incautiousness, is subject to the punishment extraordinary, moderated according to circumstances. ${ }^{\text {? }}$

1 Carpzovii, prax. Rer. Crim. quaest. 33 Ibique Boehmer, in Observ.

2 The Author refers to a case of the Attorney General in Amsterdam v. J. B. F. van Gooch, art. 250320 ; and asks, whether any person can question the correctness of capital punishment for this crime? He states, that Schepenen, at Rotterdam, offered their doubts in 1798, but that they were briefly contradicted by Memorial of the Supreme Court of Holland, inserted in the Records of the first Chamber of the Representatives, under date of 17th August, 1798.

[3 Voet, ad tit.ff. ad Leg. Corn. de Sicar. n. 9.]

4 Boehmer, ad Const. Crim. Carol. art. 148.

5 Reference is made to [part 2] sect. [7] of van der Linden's Book [p. 221 Seqq.].

6 Quistorp, § 235.

7 Boehmer, ad Const. Crim. Carol. art 140.

$\dagger \quad$ Orig. $\S 8$. 


\section{SECT. XV \\ Punishment in Particular for Parricide and Infanticide.}

$\dagger$ The punishment for Parricide was very severe among the Romans. The culprit was sewn up in a sack, with a live dog, a cock, an adder, and an ape; and being left to the vengeance of those animals, he was thrown with them into the nearest sea or river. ${ }^{1}$ We have no such punishment with us; but wilful Parricide is punished by breaking on the wheel ; and where it is not directly intended, but follows in consequence of some unlawful attack, or wounding, then the punishment of the sword, or gallows, is inflicted. ${ }^{2}$

Infanticides are strangled; and if death has been caused by imprudence or neglect, the extraordinary punishment of imprisonment is awarded. ${ }^{3}$

The punishment for procuring Abortion, or destroying the fruit in the womb, depends greatly upon circumstances. It is to be inquired, how old the fruit was, or whether it had given any sign of life; - what means were resorted to, to procure abortion; - has the mother done it of her own sole accord, or was she moved thereto by the persuasions of others. The degree of punishment, mostly corporal, will follow the distinctions to be made, according to those circumstances. ${ }^{4}$

It is the same relative to the exposure of infants, as Foundling. If the exposure be made with the intent to destroy the child, it is direct murder, and the punishment capital; but if such design is not evident, the punishment extraordinary is inflicted, which may be either imprisonment, corporal punishment, or banishment. ${ }^{5}$

\section{SECT. XVI}

\section{Crimes against the Honour or Reputation of our Fellow Creatures}

*Those termed Defamations (injurien) have the consequences of a civil action, to obtain an honorable and profitable redress ( $l$ 'amende, honorable and profitable) ${ }^{6}$

It is seldom that mere defamation will become a subject of criminal inquiry, unless accompanying circumstances give rise to it: as in cases where a person has published libels, wherein the Supreme Power, or the Members of the Government

1 J. F. Ramos, Errores Triboniani de Poena Parricidii (L. B. 1728).

2 Voet, ad Tit.ff. ad Leg. Pomp. de Parric. N. 4.

3 Voet, d. L.; Boehmer, ad Const. Crim. Carol. art. $131 \S 20-22$.

4 Boehmer, d. l. art. 133 § 7 Seqq.; S. V. Leeuwen Cens. For. part 1 lib. 5 ch. 15 No. 5.

5 Boehmer, ad Const. Crim. Carol. art. 132; J. Moorman's Treatise on Crimes and Punishments b. 2 ch. 7.

6 Reference is made to Van der Linden, 1 st book, sec. $16 \S 4$.

$\dagger \quad$ Orig. § 13.

$\$ \quad$ Vide Appendix, Letter A.

* Orig. $§ 16$. 
are defamed or injured. ${ }^{1}$ In the cases too, where the defamatory words have been accompanied by acts of violence; ${ }^{2}$ or when they are of that nature, that the public peace becomes disturbed by them (as is often the case with those who choose to be their own judges). ${ }^{3}$

\section{CHAPTER IV \\ Of Crimes relating to the Property of Others}

Persons guilty of this species of offence are those coming under the description of Thieves, Robbers, Persons guilty of Fraud, Peculators, Prevaricators, and Traitors; Gamesters, Bankrupts, Usurers. We will treat briefly of each in order.

\section{SECT. I \\ Of Theft}

Theft, or stealing, is when a person possesses himself of the moveable property of another, without the knowledge or consent of the owner, with a view of appropriating the same to his own use or advantage. ${ }^{4}$

Theft is either simple (or petty larceny) or qualified, which means aggravated by circumstances attending it. Burglary, or house-breaking, for instance; if the thief come armed with guns and other weapons; if the theft be committed twice, thrice, or oftener; if the property stolen was deposited in some closed place, - such as fish stolen out of a private fish-pond, the stealing of fruit out of gardens and orchards, the stealing of wood, cutting up or destroying plantations, stealing cattle out of the field; if the theft also be committed by people or servants belonging to the house, to whose care the articles have been entrusted; if it be committed by soldiers, as guards over the property; if the goods he stolen from persons busily employed in securing the same from fire or flood. All these are termed so many qualified species of theft.

With respect to the punishment for thieving, it is established by the Dutch Law: ${ }^{5}-$

1. That all theft should be punished for the first time, by scourging and branding; for the second time, by scourging, branding, and banishment from the Province of Holland and West Frisia; and for the third time, by hanging.

2. That thefts committed with violence, and burglary, should be punished with death, i.e. by hanging.

1 Placc. of Holland March 1st, 1754, Gr. B. of Placc. vol. 8 page 570.

2 Voet, ad Tit.ff. de Injur. No. 18.

3 Groenewegen, de Leg. abr. ad § 1 Inst. de vi Bon. Rapt.

4 Quistorp, § 341.

$5 \quad$ Placc. of Holland December 16, 1595, March 19, 1614, Gr. Book of Placc. vol. 1 col. 482 \& 485. 
3. The stealing of cattle, robbing of mills, pole work, the materials of sluices, of bridges, and other works; stealing ploughs, waggons, and the like; being modes of stealing particularly injurious to the public good, should be punished with death.

4. That a similar punishment should be awarded against purchasers of stolen goods. $\uparrow$

It is, however, certain, that custom, in conformity to many decrees, both of the Superior and Inferior Courts, has mitigated, in some degree, the severity of the above regulations; and many instances occur, where simple theft is punished by scourging, or even with less punishment, and qualified theft not always with death; but in lieu, severe corporal punishment. ${ }^{1}$

With respect to the stealing of cattle, the punishment varies in different places. In some they are very severe, and the punishment is always hanging; in others it is only severe corporal punishment. ${ }^{2}$

\section{SECT. II \\ Of Robbery}

Robbery differs from theft; it is stealing by force. ${ }^{3}$ The sort and degree of violence used, may considerably vary. It is clear, however, when this crime is committed on the public road, or in a person's house, it merits capital punishment; yet, there are in these, some cases that allow of mitigation, when a corporal punishment, or flogging, is judged sufficient. ${ }^{4}$

Sacrilege and Kid-napping are two aggravated species of robbery.

Sacrilege is a robbery committed relative to goods or property appropriated to religious purposes, and particularly heinous with respect to alms that have been collected for the poor. However superstitious notions with respect to religious matters may have caused some excess formerly in the prosecution for this offence, the punishment now is moderated by better reason and judgment; yet it is a crime sufficiently heinous, comes under the term of one qualified, and is to be punished by severe corporal punishment, according to circumstances. ${ }^{5}$ Kid-napping (plagium) takes place, where a person is forcibly concealed for some interested purpose. The punishment for this crime is usually scourging and branding; and under some

1 Reference is made to a certain Juridical Treatise in Letters, respecting F. G. Meyer, by Dr. J. Schaap [Van der Linden referred here to J. Scharp's Brieven over F.G. Meijer] (Rotterdam, 1797,) page 128.

2 Voet, ad Tit.ff. de Abig. No. 4.

3 Boehmer, ad Const. Crim. Carol. art. 126.

4 Ley[s]er, Medit. ad Pand. tom. 8 spec. 539; Voet, ad Tit ff. de vi Bon. Rapt. No. 4.

5 Quistorp, § 386-390; Voet. ad Tit.ff. ad Leg. Jul. Pecul. No. 5.

$\dagger \quad$ Knowing them to be so. 
circumstances of an aggravated nature, which are to be judged from the design of the concealment, a capital punishment would be awarded. ${ }^{1}$

\section{SECT. III Of Frauds (Falsiteit)}

A wilful and designed concealment of the truth, tending to injure another, is termed a fraud or a fraudulent act. To establish the guilt of such an act, two things are requisite: -

1. A wilful and malicious design, ${ }^{2}$ which ought to be fully proved; at least, to a great degree of probability such designs should be apparent ${ }^{3}$ for without such design the act may be an error or misconception, and consequently not punishable. ${ }^{4}$

2. There must be some actual injury done to another person; ${ }^{5}$ simple lying or falsehood not having either of these requisites, is therefore out of the reach of penal law. ${ }^{6}$

Frauds may he committed both by acts and by neglect; also, by words, writing, \&c. ${ }^{7}$

It speaks for itself, that according to the greater or less degree of malice observable in the design, the greater or less injury occasioned by the fraud, the crime may very considerably vary in degree of atrocity or criminality. The crime, for instance, is considered of greater enormity, where design is shewn to defraud the Government, by imitating Government or other public stamps, - the signatures of public functionaries. ${ }^{8}$

The vigilance, indeed, of the Judge is often exercised, in endeavouring to detect the imitation of the signatures of private persons; and it is well employed in so doing, on account of the mischievous consequences to the community at large attending such sort of fraudulent actions.

It is impossible accurately to point out the great number of cases, the very many instances, in which fraud may be committed. ${ }^{9}$ It extends also to defrauding the public revenue; $;^{10}$ and consequently, to all fraudulent acts, whether of a public or private nature. $^{11}$

1 Voet, ad Tit. ff. de Leg. Fab. de Plag.

2 L. 1 pr.; L. 2; L. 23; L. 32 pr.ff. ad Leg. Corn. de Fals.

3 L. $18 \S 1$ ff. de Probat.; L. 20 C. ad Leg. Corn. de Fals.

4 D. L. 20; C. L. 31 ff. eod.

5 Arg. L. 23 ff. ad Leg. Corn. de Fals.; Boehmer, ad Const. Crim. Carol. art. $112 \S 1$.

6 Ley[s]er Medit. ad Pand. tom 9, spec. 594.

7 Boehmer, Elem. Jur. Crim. sect. 2 p. 324.

8 Quistorp, § 410.

9 Voet, ad Tit. ff. de Leg. Corn. de Fals. No. 6.

10 This fraud is punished by fine only; in case of poverty, by corporal punishment. Gen. Ord. August, 1749 art. 4, - unless it should be combined with other crimes, such as Perjury, Falsifying Notes, Passports, \&c.

11 D. D. ad Tit.ff. Stellionat. 
The degree of punishment for fraudulent acts, will, of course, be commensurate with the degree of guilt, and the injurious consequences belonging to them. The Emperor (Charles V.), however, made the punishment, generally, to be hanging; ${ }^{1}$ and even now, many cases of an aggravating nature may occur, so as to make the crime capital; ${ }^{2}$ yet, the simple rule of common justice seems to require, that the punishment for fraud should be arbitrary, or discretionary; and that it should be punished according to its magnitude, either by scourging, with or without branding, imprisonment, banishment, or pecuniary fine. ${ }^{3}$

\section{SECT. IV \\ Of Peculation}

This is a species of public fraud. It is when a person purloins the public money entrusted to his care or custody, and instead of employing it to its proper purpose, converts it to his own private use. ${ }^{4}$

The punishment for this crime, over and above refunding what has been peculated, is, generally, the loss of situation, imprisonment, banishment, \&c. ${ }^{5}$

It will tend greatly to aggravate the offence, if such functionary shall have, previous to his entering into office, taken an oath not to act fraudulently or unjustly, as he has thereby incurred the additional stigma and penalty of perjury.

It is highly culpable in those holding situations under Government, and other public functionaries, if, unmindful of the duty they owe to themselves and the State, they suffer themselves to be bribed by presents and donations; ${ }^{6}$ and as the circumstances of this crime are more or less aggravated, the punishment, which is arbitrary or discretional, will he more or less severe. Loss of office, proclamation of their guilt, banishment, pecuniary fine, \&c. will, according to circumstances, be the adjudged penalties. ${ }^{7}$

\section{SECT. V}

\section{Of Treachery, Chicanery, and Prevarication, among the Practitioners of the Law}

Those Attorneys or Law Agents are truly deserving of punishment, who, instead of promoting and defending the interests of their clients, side with their opponents

1 Edict January 30, 1545, G. B. of Placc. vol. 1 col. 383.

2 Boehmer, ad Const. Crim. Carol. art. 112 § 6; [Boel] Privil. of Amsterdam p. 27.

3 S. van Leeuwen Cens. For. part 1 lib. [5] cap. 6 No. 4; Voet, ad Tit. ff. ad Leg. Corn. de Fals. No 4.

4 Crimen Residui L. 4 § 4 ff. ad Leg. Jul. Pecul.

5 Quistorp, § 417; Voet, ad Tit. ff. ad Leg. Jul. Pecul. No. 6.

6 Tit.ff. de Leg. Jul. Repetund.

7 Voet, ad d. $t$. No. 3. 
for some pecuniary advantage, and betray their cause. $\uparrow^{1}$ According to the treachery displayed, and the loss sustained by the injured party, in such nefarious cases, the punishment for this crime will be greater or less. This is usually by suspension from their offices, cancelling their admission to them, banishment, fines, \&c. ${ }^{2}$

\section{SECT. VI \\ Of Gaming, Cheating therein, and of Games of Hazard}

Among offenders particularly obnoxious to a civil community, we reckon Gamesters, especially those guilty of fraudulent practices, or cheating; - according as their conduct is more or less atrocious, - the former are punished with corporal punishment, imprisonment, or banishment.

With respect to playing for money at games of mere hazard, independent of the nullity of actions to recover what was lost or promised, ${ }^{3}$ local and general laws have been applied in different places. The punishment is arbitrary, mostly by fines, not only against the offenders, but also against those who lend their houses to carry on such practices. ${ }^{4}$

\section{SECT. VII \\ Of Bankruptcy}

Against persons failing in business, and becoming bankrupts, or insolvent, no direct penal law exists with us. The capital punishment decreed by the Emperor (Carl. Quint.) ${ }^{5}$ against such, has, from its evident absurdity, (setting aside the cruelty and harshness of such a law) never been in force. It were very desirable, however, that by some judiciously framed law ${ }^{6}$ provision were made against such encumbering members of society. Those who are found guilty of fraud, or other known crimes, are, however, liable to various modes of prosecution. ${ }^{7}$

$1 \quad T[i]$ t. ff. de Praevar.

2 Voet, ad T. No. 3.

3 De Groot's Introd. b. 3 ch. $3 \S 49$.

4 Placc. of the Court of Holland 27th April, 1723, 18th January, 1732, 10 March, 1749; Regul. of Amsterdam vol. 1 p. 115 and vol. 2 p. 506; of the Hague 22d Dec. 1704; of Beverwyk art. 18.

5 Edict October 4, 1540 art. 2, Gr. B. of Placc. vol. 1 col. 311.

6 Such a Law was framed in Zealand, dated June 27, 1776, G. B. of Placc. vol. 9 page 529, - in Holland it was not put in practice; V. Zurek Code Bat. Art. Bankeroietiers, [Van der Linden: Zurck Cod. Bat. Art. Bankeroutiers $] \S 2$ No. 3. But it has lately become a subject in the Plan for a Crim. Code, b. 4 ch. 4, under the title Criminal Bankrupt (Misdadige Bankbreuk).

7 Quistorp, § 442; Ord. for the Chamber of Insol. Estates at Amsterdam art. 24, 36, 39.

$\uparrow \quad$ There is hardly any thing more base. 


\section{SECT. VIII \\ Of Usury and Swindling}

Against Usurers, namely, persons taking immoderate and illegal interest for monies lent by them, and those termed Swindlers, who cajole or trick people out of their money; - as their offences come under the head of laws enacted against frauds in general, punishments adapted to their different degrees of culpability, will be there found. ${ }^{1}$

\section{CHAPTER V \\ Of Crimes of a Licentious or Immoral Nature}

To this fifth and last species of crime, viz: of Incontinence, or habits of licentious indulgence, we bring Adultery, Polygamy, Rape, Fornication, Concubinage, Sodomy, and Incest.

\section{SECT. I \\ Of Adultery}

Adultery is carnal connection between a married person, man or woman, and any other not the partner in wedlock. ${ }^{2}$

Adultery may be committed between two married persons, and this is called double Adultery; when one of the parties only is married, it is termed simple.

The culpability arises from its being a breach of that mutual faith, which is pledged by married persons to each other respectively, at the time of entering into the state of wedlock. Thus, it cannot take place with persons who are only[ $\dagger]$ engaged or betrothed to each other; ${ }^{3}$ but it may, relative to those married persons, who are separated from bed and board; ${ }^{4}$ as this act, though mutual, does not dissolve the marriage tie.

The crime of Adultery is committed, when those acts or means are employed, which nature has ordained for the conjunction of the sexes, although that which is the cause of pregnancy, may not have occurred. ${ }^{5}$

The punishment for Adultery between two married persons, or double adultery, is the banishment of both for 50 years, and a fine of 1000 Guilders. The man is declared dishonored, and thrown out of his situation, and rendered incapable in

1 Quistorp, § 449; Voet, ad Tit. ff. de Usur. No. 5.

2 C. 15 caus. 32 qu. 5.

3 Boehmer, ad Const. Crim. Carol. Art. $120 \S 3$.

4 The author refers to his 1 st book Ch. $3 \S 9$ on separations.

5 Matthaeus, de Crim. Lib. 48 Tit. 3 Cap. 2 No. 7, 8, \& 10.

[ $\dagger$ The typeset document ends here.] 


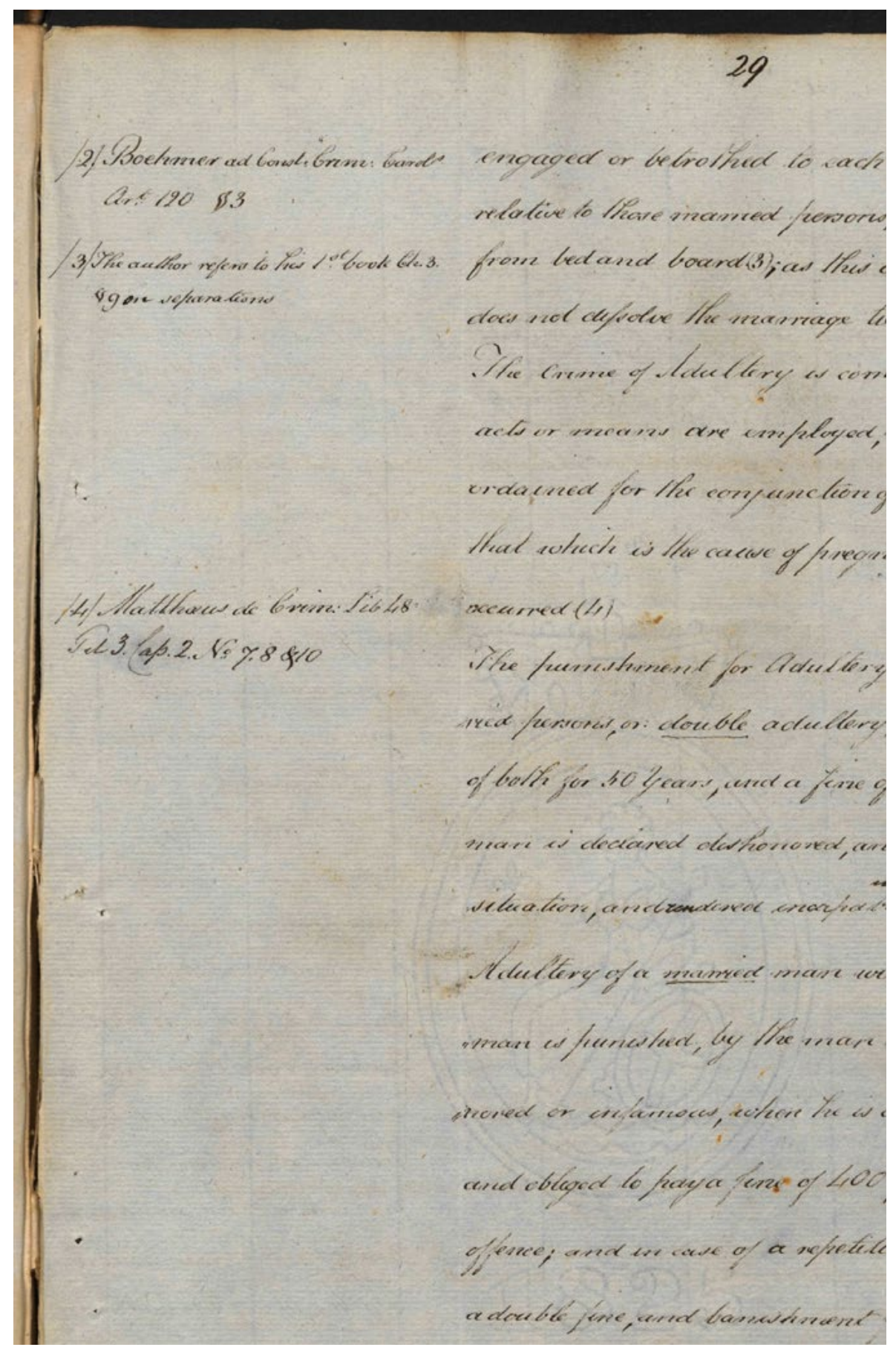

Reproduction of the first page of Borcherds' manuscript that had not been typeset 
future of holding any such. Adultery of a married man with an unmarried woman is punished, by the man being declared dishonored or infamous, when he is deprived of his office, and obliged to pay a fine of 400 Guilders for the first offence; and in case of a repetition of the crime, with a double fine, and banishment for 50 years. And with respect to the woman, she is to be confined for 14 days upon bread and water, and, in case of repetition, to be banished for 50 years.

If the adultery be committed between a married woman and an unmarried man, the man is confined for 14 days upon bread \& water, and he pays a fine of 400 Guilders, and repeating the offence, is banished for life -. The woman, in that case, is banished for 50 years. ${ }^{1}$ In consequence of the difficulty, sometimes, of proving this crime $^{2}$ it has been allowed to public prosecutors to enter into some sort of composition relative to the punishment. ${ }^{3}$

\section{SECT. II \\ Of Polygamy}

If any person during a former marriage, premeditatedly solemnize a marriage with another, and carnal conversation ensue, it is called bigamy; and Polygamy, if with more than one. ${ }^{4}$ The punishment for this crime, under aggravating circumstances, is sco[u]rging, and banishment; or otherwise, the offenders are publicly exposed upon a scaffold, and banished. ${ }^{5}$

\section{SECT. III \\ Of Rape}

Under this crime we comprehend, not only ravishing, or carnally knowing by force, but the forcibly carrying away of a woman, or girl, against their own consent. Our criminal estimation of this offence, will depend greatly, on circumstances of aggravation, or extenuation evidenced in the Act. Under the former, we reckon those cases, where the rape has been committed under threatening circumstances, with

1 Political Orders of 1580 Art. 15, 16, \& 17; Placc. of Holland Sept. 11th, 1677, Great Book of Placc. Vol. 3 page 507.

2 De Groot's advice in the Holland. Consultations vol. 3 Ch. 2 Pag. 707.

3 Resol. of Holland 29 July, 1679, Gr. Book of Placc. 7 Vol. Page 960; Van Alphen's Papegaay (Parrot) 2 Vol. page 523. This would be a wise and prudent regulation if the manner of settlement were limited to the exact boundaries of equitable moderation. But unfortunately, to how many public prosecutors could we with sorrow and sensation address these words, quid non mortalia pectora cogis, aura sacra fames - we ought therefore not to be surprised that the plan for a criminal code does not mention any thing of fines or compositions. But this perhaps again is an Extremity.

4 Boehmer, ad Const. Crim. Carol. Art. 121.

5 Juridic. Observ. Vol. 1 Obs. 10; V. d. Keessel, Thes. 62. 
arms or weapons, on the public road; - when the attack is made on a married woman, or an unmarriageable girl; - or upon a girl not possessing her due mental faculties, by her Guardian, Tutor, or Overseer, whose duty it was to protect her from any thing of the kind. ${ }^{1}$ According to these circumstances, the punishment for the crime will vary. Under any aggravating circumstances, the crime is Capital; under others, subject to corporal punishment, proportioned to the Offence. ${ }^{2}$

\section{SECT. IV \\ Of Fornication}

Under this, head considered as a punishable crime, is comprehended, the manner of living of those, who, for lucre's sake, or mere lewdness, lend or hire their bodies for carnal purposes. - Those who are in the habit of seducing women for the lewd purposes of others are called pimps. When they let out their houses for such purposes, and thereby obtain a livelihood, they are bawds. In many places in our country, the offence is connived at, although there are laws existing against such licentious practice.

In the crime of Fornication, the Law seems to content itself, by checking its extravagancies, which it is the particular province of the police to guard against; these, acting usually without much formal process, taking care to remove such disturbers when they are too glaring in their conduct, and they become nuisances to the neighbourhood; and correcting these bawds and whores, for their irregularities, by confinement or banishment, for a certain time. ${ }^{3}$

\section{SECT. V \\ Of Concubinage}

If two unmarried persons agree to live together, and cohabit as man and wife, it is termed a state of concubinage ${ }^{4}$ although, by the law of nature, there is nothing criminal in such transaction, ${ }^{5}$ and with the Romans it was deemed a lawful connexion; ${ }^{6}$ yet, according to our law, both for moral and political reasons, it is forbidden; and a fine of 50 Guilders is levied upon persons, thus living together, for the first month; for the second 100; \& for longer concubinage, a banishment of 10 years, and arbitrary

1 Boehmer, ad Const. Crim. Carol. Art. 118 \& 119, \& in observ. ad Carpzovii, prax. Crim. part 2 Quaest. 75.

2 Voet, ad tit.ff. ad Leg. Jul. de adult. n. 2.

3 Voet, ad d. t. no. 1; Zurck, Cod. Bat. Art. Hoererye (fornication); S. van Leeuwen, R. dutch law B. 4 Ch. 37 no. 11 .

4 Leyser, Medit. adff. Tom. 9 Spec. 585.

5 Authors mentioned by Meister, in Biblioth. Jur. Nat. \& Gent. Tom. 1 pag. 82.

6 Heineccius, ad Leg. Jul. \& Pap. L. 2 C. 4. 
pecuniary fine. ${ }^{1}$ Due warning however, is usually given to the parties, and they are admonished to dissolve the illicit connection; to which caution, if they neglect attending, they are of course punished. ${ }^{2}$

\section{SECT. VI \\ Of Sodomy}

An unnatural connexion of Man with Man, or Man with Beast, constitutes the abominable crime in question; ${ }^{3}$ a crime so contrary to every ordinance of Nature, of the divine Law, of the welfare of Civil Society, that by express statute ${ }^{4}$ it is every where made Capital $^{5}$ and punished publicly: and with us, moreover, the bodies of those executed for it are to be burnt to ashes; thrown into the sea, or exposed upon scaffolds.

\section{SECT. VII}

\section{Of Incest}

We consider in the last place, the crime of incest, as under the head of incontinence.

By this we understand the contracting of a marriage, or forming of a carnal connection, between persons, whose intermarrying, on account of consanguinity or affinity, is forbidden by the law.

The punishment for this crime varies, according to the degree of Relationship between the parties: - Incest committed between parents and children, is often punished with death - with respect to persons collaterally connected by blood, or marriage, corporal punishment, banishment etc. are made use of. ${ }^{6}$

\section{PART IV \\ Of the law of evidence; and in what manner crimes may become null or extinct}

What we have already advanced in a former book, ${ }^{7}$ relative to the different kinds of evidence of human transactions requisite in civil cases, is almost equally applicable

$1 \quad$ Political Ordin. of 1580 Art. 3.

2 Groenewegen, de Legib. abrog. ad L. 2 C. de Natur. Lib. N. 7; Brouwer, de jure Connub. Lib. 1 Cap. 27 N. 30; Voet, ad tit.ff. de connub. no. 3.

3 A. van Goudoever, dissert. de nefanda libidine (Traj. 1731).

$4 \quad$ Placc. of Holland July 21st, 1730, Gr. Book of Placc. Vol. 6 pag. 604.

5 Though no one of good principle will not agree with Montesquieu, Esprit des Loix, Liv. 12. Ch. 6, A Dieu ne plaise, que je veuille diminuer l'horreur, que l'on a pour un crime, que la Religion, la Morale, \& la Politique condamnent tour-à-tour: - Yet some times it has been doubted and not groundlessly; whether capital punishment should be just and adequate. Reference as made to a certain treatise on the punishment for this crime printed at Amsterdam 1777.

6 S. van Leeuwen, Cens. For. part 1 L. 5 C. 28 no. 6 ibique De Haas, in not.; Leybrechts, Treatise discussing the office of a Notary Vol. 1 Chap. 11 No. 10.

7 1st Book Section 17 Page 175 \& Seqq. Vide appendix for B. 
to criminal cases. There is, however, a distinction often necessary to be observed, which merits a separate consideration.

\section{CHAPTER I \\ Of Proof or evidence in general}

According to the general rule that a complete proof is required to condemn a person in a criminal process, it is necessary that these two circumstances appear:

1 st. That a crime has actually been committed.

2 ly. That it should be absolutely known, who the perpetrator of the crime is.

\section{SECT. 1 \\ Of the Corpus delicti}

The reasons for criminal inquiry, principally rest upon the certainty that a crime has actually been committed; or, as it is commonly expressed, that the Corpus Delicti be evident. ${ }^{1}$

This proof may be established by following into and examining the traces and remains left by the supposed crime. In the matter of homicide, for instance, the corpse of the person killed constitutes the Corpus delicti. In case of Frauds, the instrument or writing.

It is therefore, the first duty of the Judge, to trace and examine with scrupulous attention, (and, if required, to call in the aid of scientific persons), the Corpus delicti. This is particularly necessary in the examination of dead bodies, where a homicide has been committed; - an inspection of the tenements in which Burglaries have been committed, and matters of similar nature. $\dagger$ But, if the crime be of such a nature, that, after the perpetration, no traces are left to guide the Judgment, as in many cases of incontinency; then, it must be substantiated by other modes of evidence, or clear proof. $^{2}$

\section{SECT. II}

\section{Of Confession}

After the actual perpetration of the crime has been duly made manifest, the second question follows; namely, Who is the perpetrator. -

$1 \quad$ L. 1 § 24 ad SCt. Silan.; L. 16 C. de poen.; Boehmer, ad const. crim. carol. Art. $6 \S 10$ Seqq.

2 Leyser, Medit. adff. Tom. 8 Spec. 561 \& Tom. 9 Spec. 598.

$\uparrow \quad$ And also the instruments of destruction. 
The means of proof by which this fact is established, are Confession, personal evidence, writings, or other species of demonstrative evidence. -

The free confession of the criminal, is of the first species of evidence in criminal matters; ${ }^{1}$ with the proviso, that the truth is supported by other evidence, and the whole course of the transaction. - A complete or valid confession in Law requires

1st. That the perpetration of the crime is sufficiently apparent.

2ly. That the confession has been made before a competent judge: extrajudicial confession affords presumption but not sufficient proof. ${ }^{2}$

3rly. That it is simple and distinct; not clouded with obscurities; and that it be voluntary. ${ }^{3}$ It is, therefore, not to be obtained by any ensnaring questions; by putting words into the mouth of the accused; or to be exacted from him, by any threatening, or violent means.

4ly. That the informations, or other collateral evidence, collected by the judge, relative to the crime, should correspond with the confession.

5ly. That the particular circumstances, stated by the accused in his confession, are substantiated by further inquiry. ${ }^{4}$

6ly. That the confession contain such circumstances as the accused could not know, by any possibility, if he were innocent. ${ }^{5}$

\section{Sect. III \\ Of other species of Evidence}

If the accused person deny the accusation, either totally, or with respect to leading circumstances, or in his defence refer to matters which must appear elsewhere; then, the best and only resort, is to personal evidence. - In this, so far as regards corporal punishment, the following points ought to be taken into consideration:

1st. How far a witness is credible, is, or is not to be rejected; and this is to be determined, by a sensible and impartial judge himself. ${ }^{6} \mathrm{He}$ will more easily overlook a defect in a witness, if his evidence be given in defence of the accused, or in mitigation of punishment, than if it be intended to bear accusatively upon the prisoner.

1 L. 1.ff. de Confess.

2 Boehmer, ad const. Crim. Carol. Art. 32.

3 Boehmer, d. L. Art. 60.

4 Boehmer, d. L. Art. 54.

5 J. G. Heineccii, exercit. de religione judicantium circa reorum confessiones, in opusc. var. Syll. page 650-695.

$6 \quad$ L. 3 § 2; L. 13 ff. de testib.; Leyser, medit. ad. Pand. Tom. 4 Spec. 283. 
21y. All witnesses, unable to support their evidence by stating how the facts, or circumstances related, came to their knowledge; or who are at all non compos mentis, are totally inadmissible.

31y. Though there may be a sort of indirect and dubious statement given by a witness in his evidence, and though his credit as such, be in some degree affected; yet it does not disqualify him from giving it; as the judge afterwards, by the strength of other evidence produced, and examination into circumstances, will be able to determine, how far his evidence is to be considered credible or admissible. ${ }^{1}$

4ly. In criminal cases no evidence of a person under 20 years of age, can be admitted as full proof. ${ }^{2}$ Persons under that age may be heard; as their evidence may tend to throw light upon the case, and corroborate less acceptable evidence. ${ }^{[3]}$

Although evidence, which is termed negative, has not the strength of positive proof; yet in some cases, the contrary may be admitted: viz. when a concurrence of circumstances shows that had the crime really been committed some traces of it must have been within the witness's knowledge, and that he could not have had any interest in concealing it. ${ }^{4}$

5ly. In criminal cases of any serious import, no evidence is valid, which has not been taken before the judge, who is in the habit of examining witnesses by interrogation: each question containing a separate point, or circumstance; which question, if necessary, should be more particularly explained, in case the witness does not, in the first instance, sufficiently understand its meaning. The answers of the witness are, as nearly as possible, to be taken down in his own words.

6ly. No evidence can be admitted as valid unless verified upon oath. ${ }^{5}$ Mere [assertion] can only, at the most, be termed presumptive evidence; thus, sometimes a degree of caution is to be exercised, whether you ought to put a man on his oath or not.

\section{SECT. IV \\ Of proof by Indicia}

The different media of proof by presumptive evidence, strong appearances, demonstrative evidence, or indicia, have often been a subject of controversy among jurists; some admitting fully what others reject. ${ }^{6}$ These contradictory opinions

1 Boehmer, ad const. crim. carol. Art 66.

2 L. 20 ff. de testib.

[3 Carpzovii, prax. Crim. part 3 quaest. 114 No. 41. Seqq.]

4 [Leyser, Medit. ad Pand. Tom. 4 Spec. 286.]

5 Boehmer, ad const. crim. Carol. Art $70 \S 4$.

6 Leyser, medit. ad pand. Tom. 4 spec. 257; Boehmer, ad const. crim. carol. Art. $22 \S 4$ \& Art. 23 \& 24. Trial of J. B. F. van Goch Deduction in Revision Art. 143, 461 \& on the part of the Law Officer of Amsterdam Art. 203-863. 
however, appear to be easily reconciled, if we take care to make a due distinction between what are suspicions, or presumptive indicia; and those indicia, which are limited to such facts, as are each distinctly proved, and which could not be true, without the guilt of the accused flowing from them, as a necessary consequence.

Such sort of proof as the last, is quite sufficient, in our view of the question, to determine the punishment ordained by the law for the crime. ${ }^{1}$

\section{SECT. V \\ Of written Evidence}

However useful, \& indeed necessary, the admission of written evidence may be in civil cases, it is yet necessary to admit it with every degree of caution in criminal cases; and the reason is, that the acts passed of a criminal nature are of a more positive, and demonstrative kind, tending mostly to prove the Corpus delicti. However, sometimes, extracts out of protocols relative to the trials and sentences of accomplices; also, letters of the accused, or of others in correspondence with him, where the hand writing \& signatures are duly proved, may be admitted as evidence. ${ }^{2}$

\section{CHAPTER II}

\section{In what manner crimes may become null or extinct}

The manner in which crimes become extinct and all proceedings relative to them stopped, may be reduced to the following heads: By Punishment inflicted; By Pardon Granted; By Composition and submission; By Prescription; and by Death.

\section{SECT. I}

\section{By Punishment Inflicted}

If the delinquent, after due trial, and sentence passed, has suffered the awarded punishment he immediately becomes liberated from all further censure and prosecution for that crime: ${ }^{3}$ as justice cannot allow a man to be punished more than once for the same offence: ${ }^{4}$ - However, though the crime may be generally considered as extinct, in consequence of the penalty for it having been suffered; yet it is not so complete, but that if the delinquent were to commit the same offence again,

1 Reference is made to that memorial and the Sentence of death in that case which was confirmed when revised.

2 Quistorp, 10 part 12 Ch. $\S 707-709$.

$3 \quad$ L. 7 § 1 ff. de jur. Patron.

4 L. 23 C. de poenis. 
regard would be had, or a retrospect to that circumstance, so as to affect the future punishment by rendering it more severe. ${ }^{1}$

With respect to thieves, highwaymen, vagrants, and such like culprits of the more notorious kind, no appeal would avail. ${ }^{2}$

\section{SECT. II \\ By Pardon Granted}

Crimes may become extinct also from pardon being granted by the supreme authority.

Sometimes the pardon, for wise political reasons, is granted to delinquents of a certain class, whose acts arise solely from a state of civil discord; the number often being too great to be punished with the ordinary punishment, without danger or injury to the state. This is termed an amnesty. ${ }^{3}$ Sometimes it is granted to particular persons; not on account of any discretion any mercy that might be exercised in common cases; but for peculiar reasons of equity, which could not allow the operations of the law to take place in such cases without some peculiar hardship accruing to the guilty party. ${ }^{4}$

The sorts of pardon granted for crimes committed by individuals are as follows: 1st. Pardon may be granted for all crimes except murder, with the reservation of damages, or remuneration, to the party injured. 2ly. By a remission of the Offence granted to homicides (not murderers), or for manslaughter; on condition of making amends to the Sovereign by a pecuniary fine. 3ly. Abolition, a free and sweeping pardon, or sort of acquittance for the offence, founded upon a concurrence of very favourable circumstances relative to the person or conduct of the perpetrator, or with respect to the act committed. 4ly. By Landwinning: By which a person, who, in selfdefence has killed another, is permitted to remain unmolested within the Country. ${ }^{5}$

\section{SECT. III \\ By Composition and Submission}

Though granting pardon for crimes is the privilege of the Sovereign, and though the Judge, in ordering punishment, is bound to take into consideration every aggravating, or mitigating circumstance; yet he is equally bound, to keep within the limits of

$1 \quad$ L. $28 \S 3$ and 10 ff.; L. 22 C. de poenis; pol. Ord. Art. 3 \& 16; placc. of Holl. March 19, 1614 Art. $1 \& 4 \&$ a number of other laws.

$2 \quad$ Placc. of Holland June 17th, 1718, Gr. Book of Placc. Vol. 5 pag. 764.

3 Several instances are to be found in the Gr. Book of Placc. Vol. 2 Col. 2397, Vol. 3 page 189, 517 \& 518, Vol. 7 pag. 840, Vol. 9 pag. 420, 430, 433, 441, 444, 446, 448, 576, 578 \& 816.

4 Carpzovii, prax. Crim. part 3 Quaest. 150 ibique Boehmer, in observ. The court's opinion of Dec. 8, 1784 in the author's Judicial practice, Book 2 pag. $257 \&$ Seqq.

5 Jud. Pract. d. L. pag. 272-274. 
the law ${ }^{1}$ and not, in his decision, to oppose the dictates of mercy to the plain and necessary rules of strict justice. ${ }^{2}$ Yet in the execution of Justice, means have been introduced of ex arbitrio mitigating the punishment decreed or diverting the culprit's adjudged fate. -

1st. By having his case declared to be of a civil nature, and subject to composition. This declaration of the judge is necessary with respect to crimes, on which the law passes a heavier judgement than that of fines; ${ }^{3}$ or, where such compounding by the public prosecutor is not allowed expressly; as in cases of adultery. ${ }^{4}$

The Judge's power, too, is confined within certain limits, and such composition is never allowed in great crimes wilfully committed; such as murders, where the victims have been waylaid; or otherwise qualified; false evidence; false coining; rape etc. ${ }^{5}$

The Judge, moreover, previous to his declaring a case civil, or compoundable, [ought] to examine carefully and cautiously, whether some traces may not be discovered, which would tend to determine, that the perpetrator was actuated by malicious motives, rather than that he committed the deed through negligence, or inadvertency. If through the former, it would be a great injury to society, and subversive to every rule of strict necessary justice, to let such a person escape; for though it is of the greatest importance that the innocent should not suffer, yet it is not less so, that the villain, or perpetrator of atrocious crimes, should not go unpunished; but, on no account, is it either in the power, or consistent with the solemn and imperious duty of a judge, to allow pecuniary composition for crimes or felonious acts, which the law, for the necessary maintenance of Public peace and security, has decreed should be punished with corporal, or capital punishment, as the case may require. ${ }^{6}$

2ly. The punishment becomes extinguished by what is termed the submission of the judge; which is resorted to when a case is so very doubtful, that he cannot determine whether it is compoundable or not, and scruples to come to a determination either way. He then leans to the merciful side which the law allows him to do, and this is termed "an escape by the submission of the Judge". But for reasons above given, he should be scrupulously careful, in his scrutiny of the case, that an artful designing villain does not, by this species of discretional, and humanely devised Lenity, escape the just punishment of the law. ${ }^{7}$

$1 \quad$ L. $1 \S 4$ ad SCt. Turpil. Crim. ord. of 1570 Art. 56.

2 Resol. of Holland September 27, 1668, Gr. Book of Placc. Vol. 3 page 85.

3 Ord. of Empr. Charles of May 19th, 1844 Art. 3 \& 4; Ampliations of the Courts Instruct. 1644 Art. 30 .

4 Resol. of Holland July 29, 1679, Gr. Book of Placc. vol. 7 pag. 960.

$5 \quad$ Instruction of the Court Art. 9.

6 Jurid. Observ. in de Groot, Introd. Vol. 4 Observ. 40.

7 The author's Judic. Pract. Vol. 2 B. 4 Ch. $5 \S 18-20$. - Vide further on this subject Art. 88 of the crim. Trial published at The Cape of Good Hope on the 4th of Dec. 1819. Translator. 


\section{SECT. IV \\ By Prescription}

The prosecution in criminal cases sometimes become null, by what is termed jus prescriptionis; that is, where, after the commission of the crime, a certain time has elapsed before the prisoner is publicly accused or prosecuted.

In all cases of crime, ${ }^{1} 20$ years is the allowed period of prescription; ${ }^{2}$ no action or accusation can therefore, be brought against a person after a period of 20 years has elapsed before legal accusation. There is some peculiar distinction with respect to the crime of adultery: in which case the time of prescription is limited to five years. ${ }^{3}$

\section{SECT. V \\ By Death}

Death puts a stop to legal actions, both criminal and civil. Actio personalis cum personâ moritur. No prosecution on the body of the defunct, except in cases of high treason and in some of peculation ${ }^{4}$ can take place; and if the criminally accused person die, during trial, before sentence passed, the trial is at an end, and all further prosecution ceases, ${ }^{5}$ nor can it be extended to his heirs, even to obtain remuneration for the law expenses on the part of this prosecution to the death of the accused person on trial; for to establish the obligation on the prisoner to pay it, it is necessary, that he be criminally convicted; and consequently it cannot be forced upon his heirs ${ }^{6}$ any more than upon him till his guilt [has] been determined by due Judgment of Law.

1 Leyser, medit. ad Pand. Tom. 7 Spec. 515; Boehmer, in observ. ad Carpzovii, prax. crimin. part 3 Quaest. 141 Obs. 1.

2 L. 12 C. ad Leg. Corn. de Fals.; L. 3 ff. de requir. reis.; L. 13 pr.ff. de div. tempor. praescr.; Matthaei, paroem. 9 n. 14.

3 L. 29 § 5, 6 \& 7ff.; L. 5.; L. 28. C. ad Leg. Jul. de Adult.; Voet, ad d. t. ff. no. 22.

4 Matthaeus, de Crim. Lib. 48 Tit. 19 Cap. 3 n. 4-6.

$5 \quad$ L. $15 \S 4$ ff. ad SCt. Turpil.

6 The author's treatise on two interesting criminal cases (Utrecht 1791) \& B. Voorda's Notes on the Crim. Ordin. Art 67. 